Effects of immigration in frictional labor markets: theory and empirical evidence from EU countries

Eva MorenO-GALBIS, AHMED TRITAH 
ISSN 2110-5472 


\title{
Effects of immigration in frictional labor markets: theory and empirical evidence from EU countries
}

\author{
Eva Moreno-Galbis * \\ Ahmed Tritah ${ }^{\dagger}$
}

\begin{abstract}
Immigrants are new comers in a labor market. As a consequence, they lack of social networks and other country specific and not directly productive valuable assets affecting their relative bargaining position against employers. We introduce this simple observation into a matching model of the labor market and show that immigrants increase employment prospects of competing natives. To test the predictions of our model, we exploit yearly variations between 1998 and 2004 in the share of immigrants within occupations of 12 European countries. We identify the causal impact of immigrants on natives' employment rate using an instrumental variable strategy based on historical settlement patterns across host countries and occupations by origin countries. We find that natives' employment rate increases in occupations and sectors receiving more immigrants. Moreover, we highlight the heterogeneity of this impact across groups of immigrants and host countries along dimensions that affect immigrants-natives relative reservation wages.
\end{abstract}

Keywords: immigration, reservation wage, assimilation; European labor markets

JEL: J61; J62; J64; E24

\footnotetext{
${ }^{*}$ GRANEM (Université d'Angers), CREST, IRES (Catholic University of Louvain) \& GAINS (Université du Maine). Eva.morenogalbis@univ-angers.fr. Address: GRANEM, Université d'Angers, Avenue Francois Mitterrand, 49000 Angers cedex, France.

${ }^{\dagger}$ GAINS-TEPP. Ahmed.Tritah@univ-lemans.fr. Address: GAINS-TEPP, Université du Maine, Avenue Olivier Messiean, 72085 Le Mans cedex, France. We have benefitted from comments made by the participants at the SAM workshop (Le Mans, 2011, Nicosia 2011), PET 2012, EEA-ESSEM 2012. Fabien Postel-Vinay, Pierre Cahuc, Roland Benabou,Etienne Lehmann, Jean-Baptiste Michaud, Helene Turon and Gregory Verdugo provided helpfull comments. Remaining errors are our own.
} 


\section{Introduction}

The consequences of immigration on labor market outcomes and welfare of the host country have been extensively discussed in the economic literature, both theoretically and empirically. Indeed, the impact of immigration on a labor market has consequences in terms of inequality, countries' fiscal stances which, in-fine, influence positions in favor or against immigrants. More recently, these consequences have been hotly debated in European countries within the welfare state context. This paper analyzes the impact of an immigration induced labor supply shock on employment opportunities of European native workers.

Theoretically, the labor market consequences of immigration have been framed within a standard neoclassical labor supply, labor demand framework (see Borjas (2003), Card (2001), Card (2005), Card (2009), Ottaviano and Peri (2012)). In such a framework, in the short run, a labor supply shock fostered by the arrival of immigrants triggers a reduction in wages of competing natives, which in turn may discourage labor force participation. As a consequence, the crucial problem in this literature is to determine against which natives immigrants are competing, and then, analyze the distributional consequences of an immigration inflow (see for example Friedberg and Hunt (1995)). Yet, this framework has somewhat been challenged by the empirical findings over the last two decades. Exploiting various experiences of immigration, in the US first, and more recently in Europe, the literature has failed to find a consistent negative impact of immigrants on natives' labor market outcome. ${ }^{1}$

A more recent literature comes up with some explanation. On the one hand, one stream argues that natives and immigrants are never perfectly substitutable. Notably, according to Ottaviano and Peri (2012), immigrants and natives, in spite of having similar "observable" skills, are not perfectly substitutable in production. According to their estimations, newly arrived immigrants are substitutes with older immigrants whereas they are imperfect substitutes of natives. Peri and Sparber (2011) or D'Amuri and Peri (2014) justify this finding by considering different relative skill endowments between natives and immigrants. Whereas natives have a comparative

\footnotetext{
${ }^{1}$ Note that, an overwhelmingly majority of this literature has been focused on the impact over less-skilled natives, with the experience of the US following the 1965 Immigration Act that shifted the immigrants composition towards poorer countries and notably Mexicans; Card (1990), Altonji and Card (1991), Card (2001), Borjas (2003) are the most influential papers. For a literature review, see Borjas (1999). On Europe see Dustmann, Glitz, and Frattini (2008) for the UK, Glitz (2011) for Germany, Gonzalez and Ortega (2008) for Spain, and Ortega and Verdugo (2011) for France. Longhi, Nijkamp, and Poot (2006) offer a summary and perform a meta-analysis on the wage effect of immigrants.
} 
advantage in communications skills intensive jobs, immigrants have a comparative advantage in manual skills intensive jobs. Following an immigration induced labor supply shock, changes in relative skill prices lead natives to reallocate towards communication and language intensive tasks while immigrants become specialized in manual intensive tasks. Again, they consider in this indirect way, a complementary relation between otherwise similar natives and immigrants in terms of education and experience.

On the other hand, a second stream of literature focuses rather on the endogenous nature of technological change. Lewis (2011) looks at labor demand side adjustment, and shows, as in the recent literature on inequality and technological changes (Acemoglu (2003)), that firms adjust to unskilled labor supply shocks by adopting less skilled biased technology : an increase in the share of immigrants among lower skilled workers makes the adoption of a technology complementary with low-skilled labor more profitable, dampening their initial negative impact on wages.

All these contributions stick to the standard neoclassical framework and all the process of adjustment appeals to a form of "time consuming" adjustment coming from a complementary factor (capital, technology or natives' human capital), thus they are not suited for analyzing short term impacts of immigrants.

We propose a third factor explaining the absence of a negative impact on natives' labor market outcomes that comes from the functioning of labor markets. Whatever the labor market considered, immigrants are new comers. As a consequence, they lack of social networks, host country specific labor market knowledge and others, although non directly productive, valuable assets. For instance, one such an asset is the eligibility and amount of unemployment benefits which are conditional on past employment experience in host countries. These characteristics affect immigrants' outside option and put them in a lower bargaining position as compared to natives when they negotiate their wages with employers, making them more profitable workers. Therefore, even if immigrants are perfectly substitutable with natives in the production process their profitability for employers is higher. Following an inflow of immigrants, the average expected profit of firms operating in the receiving labor market increases, raising incentives to open more vacancies. Therefore, whatever their qualification, because of their genuine characteristics, upon arrival immigrants are always a source of a positive externality for natives as they increase the expected profit associated with a filled vacancy.

Related mechanisms have already been emphasized in some theoretical papers by Ortega (2000), Chassamboulli and Palivos (2014) and Chassamboulli and Peri (2014). However, we go beyond 
by providing causal empirical evidence on natives' employment rate responsiveness to an immigration induced labor supply shock across European local labor markets defined by occupations. Moreover, to assess the relevance of our mechanism we empirically estimate the divergent causal impact of immigration on native employment depending on the importance of the gap between the outside option of natives and immigrants. Finally, we simulate our model in order to evaluate the magnitude of the outside option gap between immigrants and natives which is consistent with the empirically estimated causal impact.

The idea of a divergent reservation wage between natives and immigrants, leading immigrants to accept lower wages, seems to be widely supported by the empirical evidence. In Algan et al. (2010), the authors estimate that, for the same characteristics (education, experience, region of residence, etc), first generation immigrants men from Maghreb earn 0.161 percentage log point less than comparable native men in France. This divergence rises to 0.262 percentage log points when considering immigrants from Africa. In Germany the gap between first generation immigrant men and comparable natives equals 0.205 percentage log points when considering immigrants from Greece, 0.17 percentage log points when considering immigrants from the former Yugoslavia and the gap falls to 0.076 percentage log points for immigrants from Turkey. According to the estimations of Algan et al. (2010), in the UK, all first generation immigrant groups earn substantially less than their natives counterparts with the gap ranging from 0.207 percentage log points for Black Caribbeans to 0.530 percentage log points for Bangladeshis. Working with Dutch data, Kee (1995) finds that the offered wage differentials between natives and immigrants equal 35.2\% when considering Antilleans, $40.5 \%$ for Surinamese, $53.5 \%$ for Turks and $44.4 \%$ for Moroccans. When decomposing these differentials between the part due to disparities in objective characteristics and the part due to discrimination, the author estimates that $35 \%$ of the log wage difference between natives and Antilleans is attributable to discrimination, and 15\% when considering Turks.

Working with US data, Card (2005) estimates that, for identical characteristics, the wage gap between men immigrants and their natives' counterparts is about 11\%. Finally, using UK data, Nanos and Schluter (2012) explore the role of unobservables (such as differences in search frictions or reservation wages) as determinants of wage differentials between natives and immigrants. They estimate that, when controlling for the divergence in the reservation wage between natives and immigrants, the migrant effect of the wage differential is reduced by almost $55 \%$. Thus, divergence in the value of the outside options (reservation wage) seems to be an important 
determinant of observed immigrants-natives wage gap. These findings corroborate the main hypothesis of our paper, according to which immigrants have a lower reservation wage with respect to natives due to their lower value of outside option.

Our paper places the functioning of the labor market at the heart of the analysis. We propose to analyze the labor market impact of immigrants within a search and matching framework à la Pissarides (1990). We believe that including search frictions is particularly relevant for European labor markets, where the presence of rigidities prevents wages to adjust and most of the adjustment is thus concentrated on the quantity of jobs available. In labor markets with search and matching frictions and relatively generous institutions, disparities in outside options (reservation wage) may account for a substantial share of wage differentials between (eligible and protected) natives and (non-eligible and unprotected) immigrants. Interestingly, immigrants wage gap with respect to similar natives seems to be more important in European countries compared to the US (see Card (2005) and Algan et al. (2010)). In the former, labor market institutions may play a specific role in increasing the relative reservation wage of natives. Particularly, since afterwards, with years of residence in the host country (when immigrants become eligible), wage differentials (for similar characteristics) tend to disappear in both the US and Europe (see Chiswick (1978), Borjas (1994) or Borjas (1999) for the US, Chiswick, Lee, and Miller (2005) for Australia, Friedberg and Hunt (1995) for Israel or Lam and Liu (2002) for Hong Kong).

With the notable exceptions of Ortega (2000), Chassamboulli and Palivos (2014), Chassamboulli and Peri (2014) or Liu (2010) we are not aware of any other study analyzing the labor market impact of immigrants on host countries using a search and matching model of equilibrium unemployment. This model provides though a simple theoretical framework along which one can analyze the short run impact of immigrants on natives' employment rate. Ortega (2000) is interested in the equilibrium distribution of workers in the host and origin countries and the employment consequences for natives in the host country. Using a standard search and matching framework he shows that, provided they have higher search costs, immigrants can improve the employment prospect of natives. Chassamboulli and Palivos (2014) also consider that immigrants have a lower outside option with respect to natives, and distinguish between skilled and unskilled immigration. They propose a nested CES aggregator, which allows skilled labor to be more complementary to capital than to unskilled labor. Using numerical simulations, the authors conclude that although the skill-biased immigration in the US between 2000 and 
2009 raised the overall net income of natives, it may have had distributional effects. Specifically, unskilled native workers gained in terms of both employment and wages. Skilled native workers, on the other hand, gained in terms of employment but may have lost in terms of wages. Finally, Chassamboulli and Peri (2014) theoretically analyze the impact of various immigration reforms on the US labor market. They conclude that legalization stimulates firm's job creation by increasing the number of workers with low reservation wage.

In all these three papers, lower outside option of immigrants is the source of the positive externality exerted by immigrants on natives and provides the main explanation for the absence of short run negative impact of immigrants on native employment. ${ }^{2}$ However, no empirical evidence has been provided to test the predictions of this model at the local labor market defined by skills and locations and no empirical evidence has been offered in support of the role of the lower outside option of immigrants. In our paper we try to fill this gap.

First, to guide our empirical investigation, we present the very basic Pissarides (1990) framework, whereby firms respond to changes in local labor market conditions by posting more or less vacancies so as to exploit all available profits: the number of jobs responds to changes in the expected profit of a filled vacancy. To focus on the pure externality effect on employment, we assume perfect substitutability between immigrants and natives and we consider a labor supply shock at the occupation level (used as a proxy for skills). Unlike previous papers immigrants and natives are therefore equally productive and perfectly substitutable. However owing to their lower outside option these immigrants are more profitable workers, which increases firms' incentives to open more vacancies. Assuming perfect wage rigidity, increasing job creation benefits natives which experience an increase in their employment rate. In an extension of the model which allows for sectoral mobility within occupations, we show that immigrants stimulate employment reallocations towards immigrants' receiving sectors. ${ }^{3}$

Second, we estimate the elasticity of native employment to changes in the share of immigrants within a local labor market defined at the occupational (skill) and country level. Labor supply shocks are analyzed within occupations to ensure that immigrants and natives are close substitute as postulated in our model and that mobility across local labor markets is limited. Next,

\footnotetext{
${ }^{2}$ These papers also introduce other sources of heterogeneity.

${ }^{3}$ The extension of the model is presented in appendix 10. We allow workers to move between sectors within the local market to take advantage of any changes in employment opportunities between sectors. While most of the literature has considered the outward displacement effect of immigration on natives we show in this context that inward displacement is also a possibility.
} 
based on the two-sectors extension of our theoretical framework we show that immigrants cause natives within a local labor market to reallocate towards sectors receiving more immigrants. In a third step, we exploit heterogeneity across immigrants and across host across countries, to provide evidence in support of our key mechanism. We start investigating whether immigrants with plausibly lower reservation wages exert larger effects, emphasizing differences with respect to immigrants' origin country and duration of residence. Next, we identify heterogeneous effects across host countries along institutional dimensions that affect immigrants-natives relative outside option gap. We emphasize differences determining the eligibility to unemployment benefits that may explain differences in unemployment benefit take-up rate between immigrants and natives.

Lately, the final objective being to go beyond a simple assessment of the theoretical prediction, we simulate the model using standard parameter values normally employed for the Pissarides (1990)'s model. We seek to determine the plausible values of the outside option gap which are consistent with the empirically estimated elasticity of natives' employment rate to immigrants' labor supply shocks.

We use data from the European Labor Force surveys from 1998 to 2004 and define the local labor market at a country and nine broad occupations level. To our knowledge, Angrist and Kugler (2003) and more recently D'Amuri and Peri (2014) are the only studies that exploit variations across European countries to identify the impact of immigrants on natives. Although none has looked at the impact at the occupational level. For a large part, the literature has been focused on the US experience or a single country case. This is a concern regarding the external validity of the results. We believe our approach is particularly relevant given the peculiarity of European labor markets plagued by higher frictions than in the US. Moreover, if wages are sticky, as it is presumably the case in Europe, then most of labor market adjustments should happen along the quantity margin. This has been overlooked in the literature which has mainly focused on wage impact.

Defining a labor market at a national level, as in the seminal contribution of Borjas (2003), but in a multicountry context, has two key advantages. First mobility between countries is costly, therefore one can mitigate the spurious correlation introduced by the possibility for natives to "vote with their feet" by moving outside the labor market whose employment prospects worsen: the so called displacement effect. Second, we can use an identification strategy that has proven powerful in the spatial approach to deal with the non-random distribution of immigrants across 
local labor markets. Indeed, the supply of immigrants in an occupation and a country responds to unobserved labor demand shocks, leading to a well known simultaneity problem. We identify the causal impact of immigrants on natives' employment rate within an occupation using an instrumental variable strategy. We extend the strategy originally developed by Altonji and Card (1991) to a multi-country-occupation setting and use historical settlement patterns across both host countries and occupations by origin countries as an instrument for current inflows. Such instrument has proven to be a strong determinant of contemporaneous inflows in the single country case. ${ }^{4}$ To date, D'Amuri and Peri (2014) are the only ones that use a similar instrument in a multicountry setting, although they do not focus on occupational choices within countries. Our main findings are three. First, immigrants exert a small but positive impact on male natives' employment rate. Doubling the share of immigrants in an occupation increases male natives' employment rate in that occupation by almost $2 \%$. No effect is found for women. Second, considering men, we find that occupational employment becomes concentrated in sectors receiving more immigrants. This inward displacement effect points to employment creation for natives in the immigrant receiving sector within the occupation. This benefits previously unemployed natives, but also previously employed natives in other sectors. Third, we find heterogenous effect across immigrants and host countries across dimensions that positively correlate with immigrants-natives outside option gap. The positive effect on native employment is all due to non EU15 and recently arrived immigrants and is found to be larger in host countries for which the gap in unemployment benefit take-up rate between similar immigrants and natives is higher. These last set of empirical results supports our view that the outside option gap is a relevant mechanism.

Finally, numerical simulations show that for almost all values of immigrants-natives outside option gap, the model is able to replicate the elasticity of natives' employment rate to an immigration driven labor supply shock. The numerically estimated elasticity is not statistically different from the empirically estimated causal elasticity.

The rest of the paper is organized as follows. Next section presents our basic one sector matching model that allows us to provide a rationale for our empirical results. Section 3 discusses data and gives some relevant descriptive statistics. Section 4 presents our empirical specification choices and discusses the identification strategy. Empirical results are reported and discussed in section 5. The relevance of our mechanism (divergent outside option) is tested in section 6 . Section 7

\footnotetext{
${ }^{4}$ See Card (2001), Card (2009) for the US and Gonzalez and Ortega (2008) for Spain among others.
} 
numerically estimates the gap between the value of the outside option of natives and immigrants that is consistent with the empirical estimations. Section 8 concludes.

\section{The model}

We present a simple theoretical framework which serves as a guideline for our empirical investigations and allows us understanding the economic rationale behind results presented in sections 5 and 6. Other theoretical contributions (see Ortega (2000), Chassamboulli and Palivos (2014) or Chassamboulli and Peri (2014)) have emphasized disparities in search costs as the source of a positive externality of immigrants on native employment. Here, we seek to present the simplest search and matching framework that can easily deliver a reduced form empirical strategy. In particular, we will focus on a local labor market in which immigrants and natives are perfectly substitutes. To emphasize the effect on employment we also assume perfect wage rigidity. ${ }^{5}$ For the sake of generality, we consider a local labor market composed by two types of labor suppliers, immigrants and natives who differ with respect to their outside opportunities of employment. For instance, immigrants arriving in the host country are likely to be non-eligible to the unemployment benefit, they are likely to have a lower value of domestic production or leisure than natives and they certainly lack of social networks and other valuable assets. As a result, when considering the immigrant population as a whole, their average outside opportunity of employment is likely to be lower than that for natives. ${ }^{6}$

\subsection{The matching process}

We use the subscript $j=N, I$ when referring to a native or an immigrant (foreign born) worker. The workforce $P$ is such that $P=P_{I}+P_{N}$. Natives and immigrants may be employed $\left(n_{j}\right)$ or unemployed $\left(u_{j}\right)$, and the number of vacancies is denoted by $v$. The matching function can be written as: $M=m\left(v, u_{N}+u_{I}\right)$. We assume a standard Cobb-Douglas matching function of the form $M=m_{0}(v)^{1 / 2}\left(u_{N}+u_{I}\right)^{1 / 2}$. Labor market opportunities are described by the

\footnotetext{
${ }^{5}$ Most authors and notably Chassamboulli and Palivos (2014) or Chassamboulli and Peri (2014) calibrate their model to simulate the effect of observed immigration on wages of different skill groups of natives. Instead, our aim is to identify a causal impact of immigrants on natives' employment rate using reduced form estimations guided by our theoretical framework.

${ }^{6}$ Obviously, we could also introduce productivity differences. However, since the main objective of the paper is to underline the role of the gap among reservation wages of natives and immigrants, we will consider that both types of workers are identical apart from the reservation wage.
} 
market tightness variable $\theta=v /\left(u_{N}+u_{I}\right)$. The probability for a firm to fill an empty vacancy equals $q(\theta)=M / v$. The probability of finding a job for an unemployed worker is given by $p(\theta)=M /\left(u_{N}+u_{I}\right)$.

\subsection{The agents' behavior}

\subsubsection{Workers}

Employed workers are paid a wage $w_{j}$. Jobs are destroyed at the exogenous probability $s$. The asset value of employment for natives and immigrants is respectively given by:

$$
\begin{aligned}
r E_{N} & =w_{N}+s\left(U_{N}-E_{N}\right) \quad \text { for natives } \\
r E_{I} & =w_{I}+s\left(U_{I}-E_{I}\right) \quad \text { for immigrants }
\end{aligned}
$$

where $U_{j}$ stands for the asset value of unemployment and $w_{j}$ for wage. As shown in section 2.3, due to their lower outside opportunity of employment, immigrants are willing to accept a lower wage, so that $w_{I}<w_{N}$.

The asset values of being unemployed are:

$$
\begin{array}{rlc}
r U_{N} & =b_{N}+p(\theta)\left(E_{N}-U_{N}\right) & \text { for natives } \\
r U_{I} & =b_{I}+p(\theta)\left(E_{I}-U_{I}\right) & \text { for immigrants }
\end{array}
$$

they depend on the value of the outside opportunities of employment $b_{j}$. We assume that natives have higher outside option than immigrants $b_{N}>b_{I}$. This is the unique difference between immigrants and natives within the local labor market.

\subsubsection{Firms}

From the firm's point of view, the asset value associated with an empty vacancy is given by minus the cost of posting this vacancy, $\gamma$, plus the surplus obtained by the firm if it manages to fill that vacancy with a native worker or with an immigrant. The firm can only observe the worker's type at the time of the match and cannot discriminate between unemployed natives or unemployed immigrants. Firms cannot thus select their applicants. The possibility of rejecting an applicant that provides a positive surplus is not considered here. Actually, it is optimal for firms to fill the vacancy as far as the surplus associated with the match is positive rather than leaving it unfilled and bear a per period cost $\gamma$ while waiting for a better worker to come in. 
The value of an empty vacancy is given by:

$$
r V=-\gamma+q(\theta)(\bar{J}-V)
$$

where $\bar{J}$ represents the expected value of a filled vacancy. The value of a filled vacancy is defined by the instantaneous profit $h-w_{j}$ associated with the job (productivity minus the wage) plus the expected loss if the vacancy becomes empty due to an exogenous job destruction shock :

$$
\begin{aligned}
& r J_{N}=h-w_{N}+s\left(V-J_{N}\right) \\
& r J_{I}=h-w_{I}+s\left(V-J_{I}\right)
\end{aligned}
$$

The expected value of a filled vacancy results from the weighted average $\bar{J}=\omega_{1} J_{I}+\left(1-\omega_{1}\right) J_{N}$, where $\omega_{1}=\frac{u_{I}}{\left(u_{N}+u_{I}\right)}$.

Firms open vacancies until no more profit can be obtained so that, at the equilibrium, the free entry condition $V=0$ applies, i.e.:

$$
\frac{\gamma}{q(\theta)}=\bar{J}
$$

The cost born by the firm while the vacancy remains empty must equal the value associated with the filled vacancy. At this equilibrium, the value of a filled job equals:

$$
\bar{J}=\frac{h-\omega_{1} w_{I}-\left(1-\omega_{1}\right) w_{N}}{r+s}
$$

We can denote the average wage paid in the local labor market as $\bar{w}=\omega_{1} w_{I}+\left(1-\omega_{1}\right) w_{N}$.

\section{$2.3 \quad$ Wages}

There are two common concepts of wage bargaining. According to one concept, employers set wages and other terms and hire the most qualified applicant willing to work on those terms. The terms are offered to applicants on a strict take-it-or-leave-it basis. A second common concept, which forms the basis of an extensive literature whose canon is Mortensen and Pissarides (1994), has wages and other terms of employment set by a Nash bargain. Models using this formula assume that the threat point for bargaining is the payoff pair that results when the job-seeker returns to the market and the employer waits for another applicant. One consequence is that the bargained wage is a weighted average of the applicant's productivity in the job and the value of unemployment. The latter value, in turn, depends largely on the wages offered for other jobs. This flexible-wage conclusion, however, hinges on unrealistic assumptions about bargaining 
threats, which are challenged by Hall and Milgrom (2008). Once a qualified worker meets an employer, threatening to walk away and permanently terminate the bargain is not credible. The bargainers have a joint surplus arising from search frictions that bind them together. Hall and Milgrom (2008) use the bargaining theory proposed by Binmore, Rubinstein, and Wolinsky (1986) to invoke more realistic threats during bargaining. The threats are to extend bargaining (disagreement payoff) rather than terminate it (outside-option payoff). The result is to loosen the tight connection between wages and external conditions (market tightness).

In the Hall and Milgrom (2008) model the employer makes a comprehensive job offer when finding what appears to be a good match. The model assumes that the worker always accepts it at the equilibrium. The wage is higher than it would be if the employer had the power to make a take-it-or-leave-it offer that denied the worker any part of the surplus. The worker's right to respond to a low wage offer by counter-offering a higher wage -though never used in equilibrium- gives the worker part of the surplus. The authors assume the absence of any commitment technology that would enable the employer to ignore a counteroffer.

As in recent works by Pissarides and Vallanti (2007), Mortensen and Nagypal (2007) and Nagypal (2007) we adopt the rigid wage definition proposed by Hall and Milgrom (2008). We suppose that the worker receives a payoff $b_{j}$ in case negotiation breaks down but also when the agreement is delayed. For the firm, we assume that there is no cost while bargaining continues. Firms and workers renegotiate the division of the match product $h$, so that the outcome of the symmetric alternating-offers game is simply:

$$
\begin{aligned}
& w_{N}=\eta h+(1-\eta) b_{N} \\
& w_{I}=\eta h+(1-\eta) b_{I}
\end{aligned}
$$

where $\eta$ can be interpreted as the bargaining power of each party and it is set to $1 / 2$. More generally, if one view $b_{j}$ as unemployment benefit, its value for immigrants may also depend on host country working experience. Thus, we expect $b_{I}$ to be higher and closer to $b_{N}$ for longer term stayers. This peculiarity will be used in the empirical analysis to reinforce our assumption of discrepancy between immigrants and natives outside option.

Note that $h>b_{N}>b_{I}$ (otherwise workers will prefer to remain unemployed rather than accepting a job), which implies that $w_{N}>w_{I}$. 


\subsection{Employment opportunities}

Employment opportunities are measured by the labor market tightness which is determined by the free entry condition (8). Combining (8) and (9), gives:

$$
\frac{\gamma}{q(\theta)}=\bar{J}=\frac{h-\bar{w}}{r+s}
$$

Since $\frac{\gamma}{q(\theta)}=\frac{\gamma}{m_{0}}(\theta)^{1 / 2}$, we find:

$$
\theta=\left(\frac{m_{0}(h-\bar{w})}{\gamma(r+s)}\right)^{2}
$$

Immigrants receive a lower wage than natives since the value of their outside option is lower. The presence of immigrants having a low outside option of employment in a local labor market reduces then the average wage paid by firms with respect to the situation where all workers in the market would be natives. This lower average wage rises the equilibrium market tightness $\theta$. Thus the higher is the share of immigrants among workers in a local labor market, the larger is the reduction of the average wage which increases the expected profit of a filled vacancy. The consecutive boost in firms' labor demand rises natives' probability to find a job. Natives' employment rate is thus increasing with the share of immigrants. ${ }^{7}$

\subsection{Natives' steady state employment rate}

At the equilibrium inflows and outflows from the labor market must be equalized, so that the total population remains unchanged, i.e. $\quad \dot{P}=\dot{P}_{I}=\dot{P}_{N}=0$. Without loss of generality total population is normalized to $1, P=P_{I}+P_{N}=1$.

At the steady state, entries to unemployment must equal exits from unemployment, for both immigrants and natives. Entries equal the proportion of employed people loosing their job, $s \cdot n_{j}$. Exits correspond to the proportion of unemployed workers finding a job, $p(\theta) u_{j}$. Equalizing entries and exits delivers the local labor market unemployment rate for group $j$ :

$$
s\left(P_{j}-u_{j}\right)=p(\theta) u_{j} \quad \Rightarrow \quad \frac{u_{j}}{P_{j}}=\frac{s}{s+p(\theta)}
$$

Given our local labor market assumptions, the unemployment rate is the same for immigrants and natives.

\footnotetext{
${ }^{7}$ Note that we are considering a short run effect. In the long run, immigrants' outside option is likely to converge to that of natives. Wages of natives and immigrants equalize and, as a result, the average wage is the same as before the arrival of the immigrant wave. Labor opportunities (denoted by $\theta$ ) come back to their initial level.
} 
Because total population is normalized to 1 , the employment rate equals $\frac{n_{j}}{P}=1-\frac{u_{j}}{P}=\frac{p(\theta)}{s+p(\theta)}$. Natives' employment rate equals then:

$$
\frac{n_{N}}{P_{N}}=\frac{p(\theta)}{s+p(\theta)}
$$

Natives' employment rate $\frac{n_{N}}{P_{N}}$ is increasing in the probability of finding a job, $p(\theta)$, which is itself increasing in labor market tightness $\theta$.

\subsection{Testing the assumptions and predictions of the model}

From this basic theoretical model we deduce that immigrants exert a positive externality since they are more profitable workers: although being equally productive they accept lower wages than natives. An increase in the share of immigrants in a local labor market where immigrants and natives are perfect substitute, should improve employment prospects of natives in that market. We design a strategy to empirically test the following set of results derived from the model.

First, we focus at the local labor market level, defined by occupations within a country. This insures that moving across local labor markets (country-occupation) is too costly in the short run. Moreover, and unlike age-education cells used in the literature, by defining skills at the occupation level we insure that immigrants and natives are close substitute in tasks performed. ${ }^{8}$ According to our theoretical model, native employment should increase in occupations that experience an exogenous increase in the share of immigrant workers. We seek to exploit time variations in the cross country-occupation distribution of immigrants to test this result.

Secondly, within local labor markets (country-occupation), we consider different economic sectors. Workers can move across sectors within a local labor market. According to an extension of our model to two sectors (see appendix 10), occupational employment should become more than proportionally concentrated into immigrants' receiving sectors. First, better employment prospects within a sector stimulate hiring of unemployed natives. Second, provided that immigrants sort into sectors with higher sector specific productivity, they may also stimulate job-to-job transition of already employed natives in the same occupation from non receiving sectors. That is, within occupations we are likely to observe an inward displacement towards immigrants' receiving sectors.

\footnotetext{
${ }^{8}$ As shown by D'Amuri and Peri (2014) within age-education cells immigrants and natives work in different occupations.
} 
Finally, while we cannot directly test it, we seek to provide empirical support in favor of our main theoretical hypothesis: the disparities in the option gap between immigrants and natives are the source of a positive externality on native employment. Thus we assume that $b_{i}$ may vary across different groups of immigrants. We first exploit heterogeneity among immigrants according to dimensions that affect their relative outside option, namely their duration of residence and country of origin. Second, we look for differential impact across host countries along institutional characteristics that also affect immigrants-natives relative outside options. We consider disparities of immigrants' impact across host countries that differ in the immigrants-natives unemployment benefit take up rate.

\section{$3 \quad$ Data and descriptive statistics}

The main dataset we use is the harmonized European Labour Force Survey (ELFS), which homogenizes and groups together country specific surveys at the European level (see EUROSTAT (2009)). Due to data availability, we restrict our analysis to the period 1998-2004. Our sample comprises the working age population (age 15-64) of Western European countries only. The data includes information on the present occupation for employed individuals and the past occupation for unemployed, working status (employed, unemployed or inactive) and demographic characteristics. Unluckily, the ELFS does not include any information on wages. We drop observations with missing data on country of birth, which are fundamental for our empirical analysis. In line with previous literature, we classify as immigrants foreign born individuals. Individuals are grouped into cells on the basis of their occupation used as proxy for skills and their country of work. The combination of both constitutes our local labor market. Occupations are broadly defined in 9 groups which are (1) senior officials and managers, (2) professionals, (3) technicians and associate professionals, (4) clerks, (5) service workers and shop and market sales workers, (6) skilled agricultural and fishery workers, (7) craft and related trade workers, (8) plant and machine operators and assemblers, (9) elementary occupations.

We can easily understand that moving from one country to another or from one occupation to another, even within the same country, is very costly for natives in the short run. This should circumvent the criticism addressed to local labor market approaches, which point out biases raised by the possibility for natives to leave labor markets receiving large immigration inflows (Peri and Sparber (2011)). Thus, individuals are grouped into local labor market cells (country- 
occupation) observed every year from 1998 to $2004 .{ }^{9}$ Our main labor market outcome of interest is defined as the natives' employment rate within that local labor market. We consider that non employed natives belong to the occupation of their last job. ${ }^{10}$ We exclude those that have never worked. Because last occupation of non employed workers is missing for Norway, France and the Netherlands these countries are dropped from the main analysis.

Considering the twelve European countries of our sample, from 1998 to 2004 the share of immigrants in the labor force has increased by 6 percentage points from $5.7 \%$ to $11.8 \%$, which is a large increase even compared with the US. Comparatively, in the US, this share increased from $12.7 \%$ to $14.7 \%$ over the same period (Migration Policy Institute, 2006).

The rise in foreign labor force in Europe is even more impressive if one considers the heterogeneity across occupations as shown in figure 1 . While the rise is pervasive across all occupations, it is higher for less skilled occupations. However, contrary to conventional wisdom the contribution of immigrants to more skilled occupations is also rising and important. The rest of the paper will seek to exploit changes over time in this heterogeneity across occupations within countries to identify the causal impact of immigrants on natives' employment rate.

\section{Empirical specification and identification strategy}

\subsection{The impact at the occupation level}

We start explaining the empirical specification and identification strategy for the impact of immigration on native employment at the occupational level. Therefore we consider units of observation at the country-occupation-year level as the local labor market observed every year from 1998 to 2004. Our point of departure is equation (15) which easily delivers the positive relationship between native's employment rate in a local labor market and the probability of finding a job:

\footnotetext{
${ }^{9}$ It would be interesting to investigate possible heterogeneous effects across age groups (see Smith (2012)). However, with data in hand, it will be impossible to implement our instrumental variable approach since we do not have the age of immigrants at entry.

${ }^{10}$ Given the broad definition of occupations, it is reasonable to assume that unemployed workers are essentially searching in the same occupation.
} 


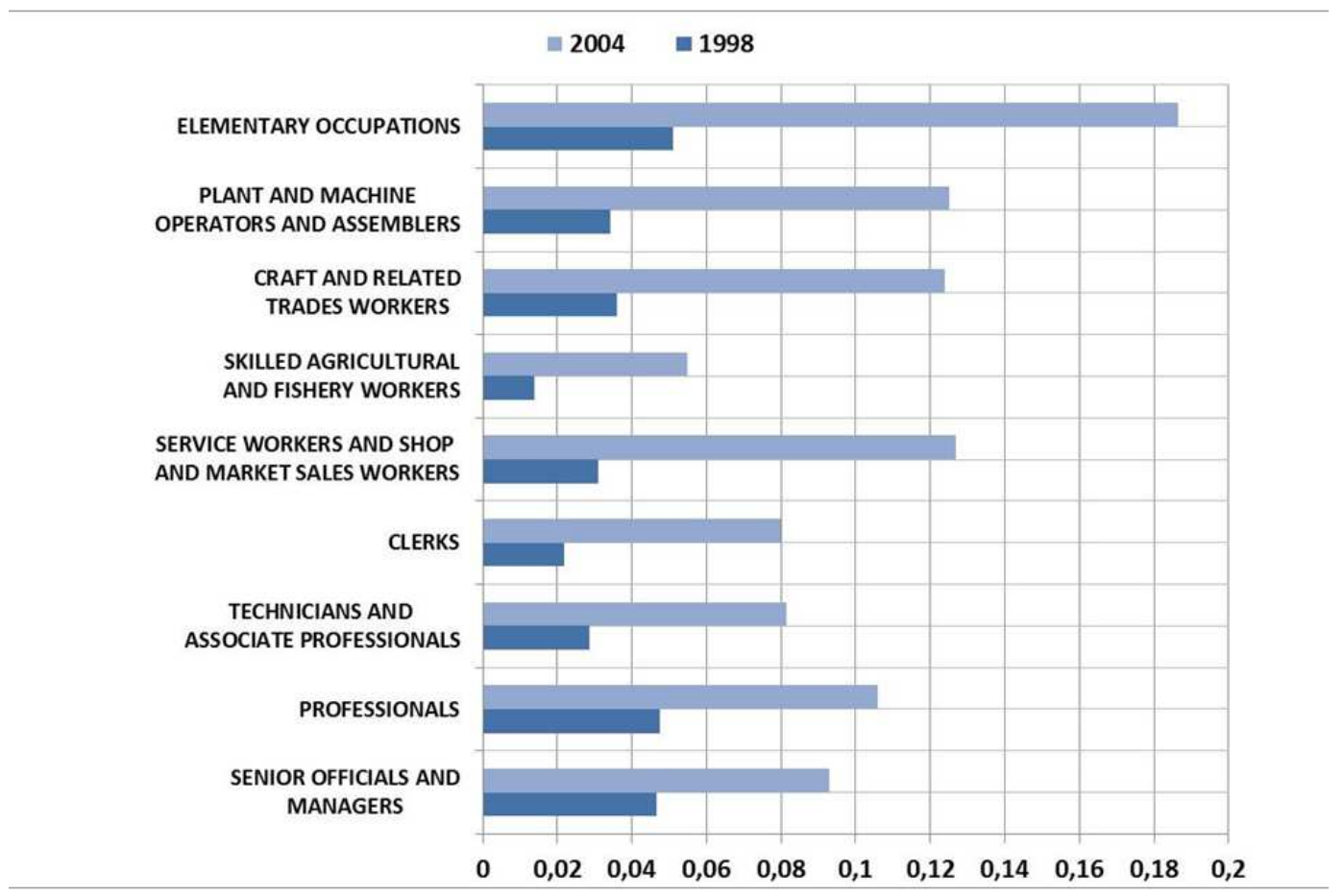

Figure 1: Contribution of immigrants to total labor force by occupation.

$$
\frac{n_{N}}{P_{N}}=F(\underbrace{p(\theta)}_{+})=F(\underbrace{m_{0} \theta^{1 / 2}}_{+}),
$$

Using equation (13), we rewrite the probability of finding a job, $p(\theta)=m_{0} \theta^{1 / 2}$, as a function of the share of immigrants:

$$
p(\theta)=m_{0} \theta^{1 / 2}=\frac{m_{0}^{2}}{\gamma(r+s)} \cdot \Omega(\underbrace{s h i m}_{+})
$$

where shim stands for the share of immigrants in the local labor market. The function $\Omega(\operatorname{shim})=$ $h-\bar{w}$ which equals the expected profitability margin of employers in a local labor market is an increasing function on the share of immigrants. Natives' employment rate also depends on the term $\frac{m_{0}^{2}}{\gamma(r+s)}$ which captures structural determinants of employment (i.e. matching efficiency, separation rate and the cost of opening a vacancy) which we assume are specific to a particular local labor market and are non time varying. Thus everything else equal, natives employment rate will be higher in labor markets characterized by better matching efficiency $m_{0}$. 
Given a population made of various local labor markets observed over several years, the natives' employment rate in a given local labor market at a particular year can be decomposed as:

$$
\log \left(\frac{n_{N}}{P_{N}}\right)_{o c t}=E\left(\log F\left(p\left(\theta_{o c t}\right)\right) \mid \text { shim }_{o c t}\right)+\varepsilon_{o c t}
$$

where $\varepsilon_{\text {oct }}$ is a random error component which is independent of shim. Taking logs on both sides of equation (16) and assuming that the conditional expectation function for $\log (F(p(\theta)))$ admits a linear approximation, we define our baseline estimating equation as:

$$
\ln y_{o c t}=\beta_{0}+\beta_{1} * \ln \operatorname{shim}_{o c t}+\alpha_{o c}+\alpha_{o t}+u_{o c t}
$$

where yoct denotes the employment rate of natives in an occupation $o$ country $c$ at time $t$. The key explanatory variable shim $_{\text {oct }}$, is the share of immigrants in the local labor market oc at time $t$. Heterogeneity across local labor markets that is country and/or occupation specific is absorbed by the country and occupation fixed effects. ${ }^{11}$ Aggregate labor market shocks are absorbed by year specific fixed effects.

We also allow labor demand shocks to have an occupation specific component due for instance to technological changes by including occupation by year fixed effects. More importantly, in all our estimations we will introduce country by occupation fixed effects to control for the sorting of immigrants into local labor markets whose structural determinants of employment are better (higher $m_{0}$ for instance) and, at the same time, have higher native employment rate. Our model allows us to relate changes in the share of immigrants in a local labor market to changes in natives' employment rate in that local labor market. Thus we seek to achieve identification by exploiting the cross-sectional time variation within local labor markets.

This wide set of fixed effects distinguishes our approach from standard cross-area studies that could not control for such factors as they either use a single cross-sectional data (Card (2001)) or a single country aggregate times series data (Borjas (2003)).

Because serial correlation within local labor market is a concern, in all regressions we adjust standard errors for clustering of observations at the occupation-country level. We also use weighted least squares with weights equal to the native population size in each occupation in the base year period $1998 .^{12}$ It is important to note that the native labor force in a cell

\footnotetext{
${ }^{11}$ The impact of labor market institutions such as the minimum wage or labor market protection, is then captured by the country fixed effect.

${ }^{12}$ Using a fixed weight insures that our results are not affected by changes in the native population size across
} 
$\left(P_{o c t}^{N}\right)$ appears in the denominator of both sides of equation (19), which may potentially create a spurious positive correlation between the immigrants' share within an occupation and the natives' employment rate. For this reason, the share of immigrants is computed by fixing the denominator to its 1998 value, our first period of data. In some specifications, we also directly control for the size of the native labor force in the cell. In this way, time variations of shim $_{\text {oct }}$ within a local labor market stem only from changes in the number of immigrants and not from native inflows or outflows.

Despite our effort to control for non time varying unobservable determinants of natives' employment rate potentially correlated with the immigrants' share within an occupation, endogeneity biases still remain a concern. ${ }^{13}$ This is the case for instance if changes in the immigrants' share within a local labor market are correlated with changes in unobserved determinants of employment within that local labor market. It is indeed plausible that within countries immigrants sort into occupations whose demand is growing. In that case, country specific occupation fixed effects are not enough, since occupation specific employment rates are not fixed within countries. We address this issue with two strategies. First, we control directly for estimated local labor market-specific productivity shocks, using a local labor market specific demand shift index. If an occupation is concentrated in an industry whose output has grown above average over the period, we expect labor demand for this occupation to have grown above average and, at the same time, to pull more immigrants and natives within that occupation. To control for this possibility, we introduce in our estimated equation, an occupation specific labor demand shift index driven by the sectoral composition of occupations at the national level : (Demand shift $)_{\text {oct }}$. Thus, we achieve identification using employment rate deviations from occupation specific trends determined by the initial sectoral composition of occupations in every host country. In the spirit of Katz and Murphy (1992) or Katz and Blanchard (1992) we construct for each country the following occupation and year specific labor demand shift index:

$$
(\text { Demand shift })_{o c t}=\sum_{k} \gamma_{o c k 1998} Y_{c k t}
$$

where $Y_{c k t}$ is the real level of production of two-digit industry $k$ at date $t$ in country $c$, and $\gamma_{o c k 1998}=\frac{E_{o c k 1998}}{\sum_{k} E_{o c k 1998}}$ is the share of workers in occupation $o$ employed in industry $k$ in 1998 in occupations due to immigrants. Using unweighted regressions or using actual weights delivers qualitatively similar results.

${ }^{13}$ Because we are including country-occupation fixed effects, endogeneity bias should arise from over-time changing labor market conditions of an occupation in a given country. 
country $c,{ }^{14}$ excluding immigrants. We interpret this index as predicted employment for workers belonging to occupation $o$ (in a given country and period of time).

The estimation of our coefficient of interest, $\beta_{1}$, will not be biased by the correlation between immigrants' inflows into a local labor market and better employment prospects for natives due to local labor market specific demand shocks driven by the sectoral composition of that local labor market.

Our second approach to deal with endogeneity biases uses an instrumental variable strategy. This requires a variable correlated with the influx of immigrants into a given labor market but uncorrelated with unobserved factors driving employment growth among natives. Our instrumental variable exploits the variation of the employment distribution of contemporaneous immigrants flows across local labor markets due to the past settlement patterns of their country peers across countries and occupations (see Altonji and Card (1991) or Card (2001)). Because of informational networks, immigrants have a tendency to cluster into local labor markets having a higher share of their country peers (see Munshi (2003)). Our instrument, inspired from Altonji and Card (1991), is constructed as follows :

$$
\phi_{c s t}=\sum_{m} S_{t o c k_{c m s 1990}} * \frac{\text { Flow }}{\text { Stock }_{O E E C D m 1990}}, t=1998, \ldots, 2004
$$

where Flow OECDmt $_{\text {is }}$ the flow of immigrants from country $m$ in year $t$ into the OECD, Stock $k_{O E C D m 1990}$ is the stock of immigrants from country $m$ in the OECD in $1990,{ }^{15}$ and Stock $k_{c m s 1990}$ is the number of immigrants from country $m$ in country $c$ having educational level $s$ in 1990. Thus, we allocate yearly inflows of immigrants between 1998 and 2004 across educational levels and OECD host countries according to their schooling and host country distribution in 1990. Data on immigrants yearly flows from origin into destination countries are gathered from the OECD and those on 1990 stocks are from Docquier, Lohest, and Marfouk (2007). We group immigrants into three distinct educational levels indexed by $s=1,2,3$ : primary, secondary and tertiary. Finally, we distribute predicted immigrants flows by educational levels across occupations according to the native's educational distribution by occupations in

\footnotetext{
${ }^{14}$ Industrial production data is obtained from the EUKlems consortium (http://www.euklems.net/). We have also constructed an index with the average level of occupation share over the whole period 1998-2004. This index gives similar results.

${ }^{15}$ We consider the stock in the whole OECD which we believe is more exogenous than considering the stock of immigrants from country $m$ in country $c$. This stock is more influenced by the economic conditions of the host country.
} 
1998. ${ }^{16}$ Specifically, our predicted inflow of immigrants across occupations, countries and over time is :

$$
(\text { Predicted inflow })_{o c t}=\sum_{s=1}^{3} \phi_{c s t} * \eta_{c s o 1998}
$$

where $\eta_{c s o 1998}$ is the share of education level $s$ employed in occupation $o$ in country $c$ in 1998 . Our instrument is then built in two steps: first we consider that the skill and host country distribution of immigrants' inflows between 1998 and 2004 is the same as in 1990. Second, we distribute immigrant inflows across occupations according to natives' educational composition across occupations in 1998. By defining our instrument in two steps we avoid potential problems associated with the fact that immigrant's distribution across occupations in 1990 could already be endogenously determined or that native's distribution across occupations may be influenced by the presence of immigrants.

Figure 2 portrays the scatter plot of the (log) share of immigrants against our (log) shift share instrumental variable. The later is obtained by dividing the predicted inflows obtained in equation (21) by the predicted number of natives in the cell in $1990 .{ }^{17}$ The figure illustrates the strong (unconditional) correlation between the two variables making, at a first glance, our shift share variable a good candidate to instrument changes in the share of immigrants within countryoccupation labor markets. ${ }^{18}$ As shown latter in this paper, this result is confirmed by the first stage IV regression. Provided flows into OECD by origin country and the past distribution of immigrants by origin country across local labor markets, are independent of current demand shocks affecting a particular local labor market, our predicted inflows can be used as an IV to identify the causal impact of immigrants on natives' employment rate.

\subsection{Assessing the inward displacement effect: impact at the sectoral level}

The assessment of immigrants' impact on local labor market has been blurred by the possibility for natives to leave the local labor market hosting more immigrants. In our context the local

\footnotetext{
${ }^{16}$ The implicit assumption is that the skill distribution of natives across occupations is not affected by immigrants.

${ }^{17}$ The number of natives in each occupation in 1990 is computed using information on the number of natives in each schooling level in 1990 and the distribution of each schooling level across occupations among natives in 1998 .

${ }^{18}$ Since our estimations include country-occupation fixed effects, it does not matter in our identification whether we divide or not by size of the local labor market in 1990.
} 


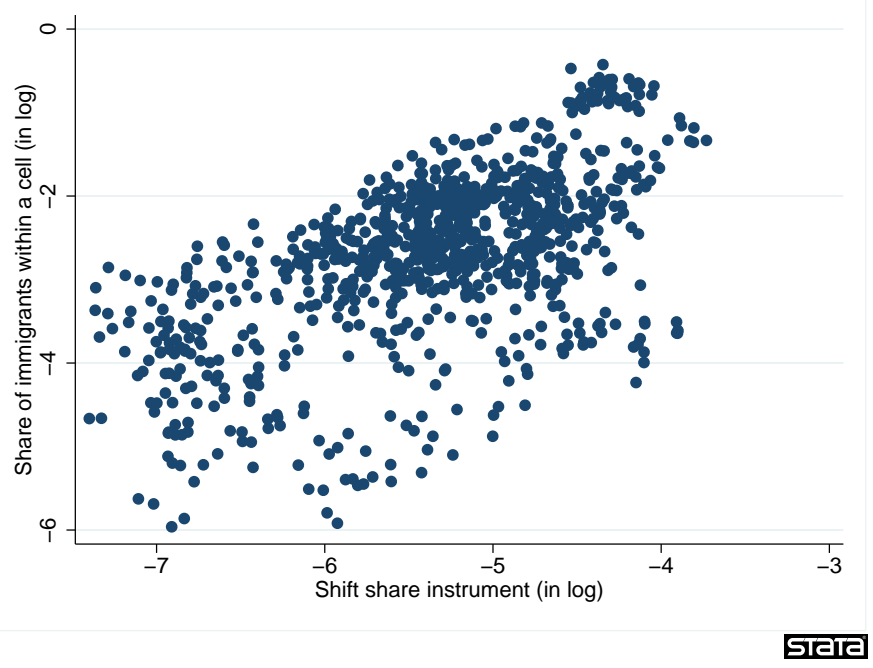

Figure 2: Immigrants predicted share based on 1990 settlement patterns across cells and immigrants yearly observed share within cells. The data are for male.

labor market is defined by broad occupations across countries, such that moving across these local labor markets is too costly. However, workers in a country within a given occupation can move across sectors in response to changing employment opportunities. Indeed, a noteworthy prediction of our search and matching model is that, within a local labor market, the employment share of sectors receiving more immigrants should expand. Improved employment opportunities in immigrants' receiving sectors benefit unemployed native workers and also pull native workers from other sectors (see the model extension presented in appendix 10).

While most of the literature has focused on outward displacement, whereby native mobility has an offsetting effect on the supply shock created by immigrants, our model is instead consistent with inward displacement. ${ }^{19}$

To investigate the direction of natives' displacement within occupations we group workers into three occupations and nine sectors (1-digit industry) in each country. The grouping of occupations is the following: the high skill covers "legislators, senior official managers" and "professionals"; the middle skill comprises "technicians and associate professionals" and "clerks"

\footnotetext{
${ }^{19}$ However, Card and DiNardo (2000) in their seminal contribution on this issue across US cities, note that "native mobility has virtually no offsetting effect on the relative supply shock created by immigration. Indeed, once controls are introduced for city-specific trends in native population growth, the data suggest that native mobility responses may slightly reinforce the relative supply effects of immigration"
} 
and, the low skill workers includes "service workers and shop and market sales workers", "agricultural and fishery workers", "craft and related trade workers", "plant and machine operators and assemblers" and "elementary occupations". ${ }^{20}$ We have to aggregate occupations when implementing the analysis at the sub-occupation level in order to ensure a sufficient number of observations per cell. ${ }^{21}$

Given our broad definition of occupations, moving across occupations is now even more prohibitively costly in the short run than before. Thus, labor mobility should occur within occupations across sectors. Generalizing the approach of Card (2005) to the specificity of our local labor market (occupations) we test for displacement of natives within an occupation occurring across sectors by running the following simple regression:

$$
\begin{aligned}
& \ln \left(\frac{\text { native and immigrant employed in occupation } o \text { and sector } j}{\text { native and immigrant employed in occupation } o}\right)_{o j c t} \\
= & \beta_{0}+\beta_{1} \ln \left(\frac{\text { immigrants employed in occupation } o \text { and sector } j}{\text { native and immigrant employed in occupation } o}\right)_{o j c t} \\
& +\delta_{c t}+\delta_{c o}+\delta_{c j}+\mu_{c o t}+\alpha_{c j t}+\varepsilon_{o j c t}
\end{aligned}
$$

Given that the number of workers in an occupation and a sector is the sum of native and immigrant workers, there is no displacement of natives if $\beta_{1}=1$. If the arrival of one immigrant triggers some natives to leave the sector $\beta_{1}<1$. While, as predicted by our model (see appendix 10) there is partial inward displacement (i.e. natives are pulled into sectors hosting more immigrants) if $\beta_{1}>1$.

Having now one additional level of observation (sectors within occupations) we allow aggregate labor demand shocks to be country specific using country by year fixed effects $\left(\delta_{c t}\right) .{ }^{22}$ At the same time unobserved occupation and sector effects are also allowed to be country specific by adding country specific occupation and sector fixed effects, respectively denoted $\delta_{c o}$ and $\delta_{c j}$. Thus, we identify the impact of an immigration induced labor supply shock on natives' sectoral mobility using variations across sectors and time within a local labor market (countryoccupation), and using variations across occupations and time within countries and sectors.

Despite our efforts to control for non observable labor demand shocks with these set of fixed effects, immigrants may still be not randomly located across sectors and occupations within countries. For this reason we enrich the set of fixed effects considered above with time varying

\footnotetext{
${ }^{20}$ Slightly different grouping of occupations into the middle and low skill groups does not affect the results.

${ }^{21}$ It is also necessary to conform with the EU-LFS publication guidelines which restrict the number of observations that can be used to compute our cell-specific employment rate.

${ }^{22}$ Using instead separately country and year fixed effects does not affect our results.
} 
country and occupation specific fixed effects in order to absorb local labor market time varying labor demand shocks $\left(\mu_{c o t}\right){ }^{23}$

More importantly, labor demand shocks across sectors have differential impact across occupations depending on their evolving sectoral composition. Assume for instance that the construction sector, which employs a relatively high share of low skill workers is booming. Then low skilled workers will be increasingly concentrated in this sector. At the same time, immigrants will be more likely to be employed in this sector. Previously, we dealt with this issue by including occupation specific labor demand shock driven by the sectoral composition of occupations. Here, a more general way to absorb the differential effect of sectoral shocks across occupations potentially correlated with immigrants' inflow, is to include a full set of country and year specific, sectors fixed effects $\left(\alpha_{c j t}\right){ }^{24}$

Lastly, we deal with remaining bias due to unobserved time varying and country specific sectoral and occupational labor demand shocks using an IV strategy which generalizes the previous approach. We consider now the case where past immigrants' networks are defined at the sector and occupation level, instead of occupations only. Specifically, once we compute the predicted number of immigrants by educational level, we obtain the predicted number of immigrants by occupation and sector by replacing in equation (21) the parameter $\gamma_{c s o}$, by $\gamma_{c s o j}$, where $\gamma_{c s o j}$ is the share of education level $s$ employed in occupation $o$ and sector $j$ in country $c$ in 1998. The first stage relation for this instrument is, as previously, strong and highly significant, suggesting that network effects do not only determine the sorting of immigrants across countries and occupations, but also within occupations of each country their distribution across the different sectors of the economy.

\section{Results}

We proceed sequentially in our estimations. First, we estimate changes in the employment rate of natives in a local labor market (country-occupation) following a change in the share of immigrants in this market. In a second step, we test whether there is displacement of total

\footnotetext{
${ }^{23}$ Given the definition of our dependent variable at the occupational level and the limited mobility across occupations and countries, this should have little effect on our estimates.

${ }^{24}$ Additionally we could further add occupation by sector by country fixed effects. However, it becomes highly saturated and the coefficient of standard errors becomes very large. Thus we prefer to deal with remaining endogeneity bias using an IV strategy.
} 
employment inside a local labor market towards immigrants' receiving sectors.

\subsection{The impact at the local labor market}

The first three columns of table 1, present OLS estimates of the elasticity of native's male employment rate with respect to the immigrants's share within a country-occupation labor market, controlling for all fixed effects specified in equation (19). Appendix 9 presents estimations without the country and year occupation specific fixed effects (column 1) and shows how results change when we successively add country-occupation and occupation-year fixed effects (columns 2 and 3). As expected endogeneity bias diminishes as more controls are included in the regression. It turns out that it is important to control for differences in local labor market specific employment rate to identify the causal impact of immigrants.

To make sure that changes in the immigrants' share within a local labor market are driven by immigrants and not by changes in the number of natives, the denominator of our independent variable is set to its 1998 value. ${ }^{25}$ Further, introducing the log number of natives in an occupation does not alter this result. We are therefore confident that, given the broad definition of local labor markets, bias due to displacement across-occupations is negligible in our context, and does not confound our estimated impact.

A potentially more serious concern is the unobserved, time varying, local labor market demand shocks that may be correlated with inflows of immigrants. As a first attempt to assess and partially control for this possibility, we introduce in column (3) of table 1 the occupation specific industry driven labor demand shift presented in equation (20). The coefficient associated with the immigrants' share remains largely unaffected. This result suggests little correlation between changes in the immigrant's share within an occupation and the labor demand shift driven by the sectoral composition of occupational employment at the national level.

In spite of controlling for country-specific occupation fixed effects and labor demand shift across occupations, OLS estimates may still be contaminated by time varying unobservable demand shocks correlated with the immigrants' share. Indeed, our labor demand shift index controls only for changes in employment within an occupation driven by the sectoral composition of occupations. But it is well known and documented (see Acemoglu and Autor (2011)) that occupational employment has been evolving overtime due to other factors. One predominant

\footnotetext{
${ }^{25}$ The estimated coefficient on the immigrants' share remains unchanged if we use instead the observed size of the workforce in the cell.
} 
Table 1: The effect of immigrants on local labor markets (country-occupation). Male sample 1998-2004

Dependent variable: $\log$ (natives' employment rate $)_{c o}$

\begin{tabular}{|c|c|c|c|c|c|c|}
\hline \multirow{2}{*}{$\begin{array}{l}\text { Specification sample } \\
\text { Estimation method }\end{array}$} & \multicolumn{6}{|c|}{ Males } \\
\hline & & OLS & & & IV & \\
\hline Independent Variable & $\overline{(1)}$ & (2) & (3) & (4) & $(5)$ & (6) \\
\hline $\ln$ (immigrants/workforce 98) oct & $\begin{array}{c}0.014^{* * *} \\
(0.004)\end{array}$ & $\begin{array}{c}0.012^{* * *} \\
(0.004)\end{array}$ & $\begin{array}{c}0.012^{* * *} \\
(0.004)\end{array}$ & $\begin{array}{c}0.022^{* * *} \\
(0.008)\end{array}$ & $\begin{array}{c}0.020^{* *} \\
(0.008)\end{array}$ & $\begin{array}{c}0.019^{* *} \\
(0.008)\end{array}$ \\
\hline $\begin{array}{l}\text { First Stage } \\
\text { Coefficient for IV in first stage }\end{array}$ & & & & $\begin{array}{c}1.060^{* * *} \\
(0.165)\end{array}$ & $\begin{array}{c}1.017^{* * *} \\
(0.164)\end{array}$ & $\begin{array}{c}1.005^{* * *} \\
(0.166)\end{array}$ \\
\hline Instrument partial R2 & & & & 0.1712 & 0.1598 & 0.1573 \\
\hline $\begin{array}{l}\text { Additional control } \\
\text { Labor demand shift index }\end{array}$ & no & no & yes & no & yes & yes \\
\hline Log number of natives workforce & no & yes & yes & no & no & yes \\
\hline $\begin{array}{l}\text { Fixed Effects } \\
\text { year by occupation } \\
\text { country by occupation } \\
\text { Observations }\end{array}$ & $\begin{array}{l}\text { yes } \\
\text { yes } \\
654\end{array}$ & $\begin{array}{l}\text { yes } \\
\text { yes } \\
654\end{array}$ & $\begin{array}{l}\text { yes } \\
\text { yes } \\
606\end{array}$ & $\begin{array}{l}\text { yes } \\
\text { yes } \\
654\end{array}$ & $\begin{array}{l}\text { yes } \\
\text { yes } \\
654\end{array}$ & $\begin{array}{l}\text { yes } \\
\text { yes } \\
606\end{array}$ \\
\hline
\end{tabular}

Units of observation are country-occupation, co, in each year $t$ from 1998 to 2004 . The dependent variable is the log share of employed natives in the country-occupation cell in a given year. The explanatory variable of interest is the log of the share of immigrants in the workforce of a country-occupation cell in a given year. The size of the workforce cell has been fixed to its 1998 value. Under all estimates we report in parenthesis heteroskedasticity robust standard errors clustered at the country occupation level. The instrumental variable is the shift share instrument computed using the Altonji and Card (1991) method. The number of observations in column (2), (3), (5) and (6) is lower due to missing data on sectoral output for Norway to compute the demand shift index.

$* * * p<0.01, * * p<0.05, * p<0.1$ 
Table 2: The effect of immigrants on local labor markets (country-occupation). Female sample 1998-2004

Dependent variable: $\log (\text { natives' employment rate) })_{c o}$

\begin{tabular}{|c|c|c|c|c|c|c|}
\hline \multirow{2}{*}{$\begin{array}{l}\text { Specification sample } \\
\text { Estimation method }\end{array}$} & \multicolumn{6}{|c|}{ Females } \\
\hline & \multicolumn{3}{|c|}{ OLS } & \multicolumn{3}{|c|}{ IV } \\
\hline & 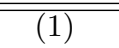 & $\overline{(2)}$ & 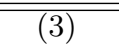 & 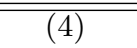 & 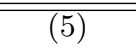 & 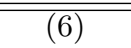 \\
\hline Independent Variables & & & & & & \\
\hline $\ln$ (immigrants/workforce 98)oct & $\begin{array}{l}-0.003 \\
(0.006)\end{array}$ & $\begin{array}{l}-0.002 \\
(0.007)\end{array}$ & $\begin{array}{c}-0.003 \\
(0.007)\end{array}$ & $\begin{array}{c}0.006 \\
(0.011)\end{array}$ & $\begin{array}{c}0.010 \\
(0.014)\end{array}$ & $\begin{array}{c}0.005 \\
(0.014)\end{array}$ \\
\hline Coefficient for IV in first stage & & & & $\begin{array}{c}1.167^{* * *} \\
(0.203)\end{array}$ & $\begin{array}{c}1.032^{* * *} \\
(0.210)\end{array}$ & $\begin{array}{c}1.039^{* * *} \\
(0.213)\end{array}$ \\
\hline Instrument partial R2 & & & & 0.1597 & 0.1324 & 0.1339 \\
\hline Additional control & & & & & & \\
\hline Labor demand shift index & no & no & yes & no & no & yes \\
\hline Log number of natives workforce & no & yes & yes & no & yes & yes \\
\hline $\begin{array}{l}\text { Fixed Effects } \\
\text { year by occupation }\end{array}$ & yes & yes & yes & yes & yes & yes \\
\hline country by occupation & yes & yes & yes & yes & yes & yes \\
\hline Observations & 654 & 654 & 606 & 654 & 654 & 606 \\
\hline
\end{tabular}

Units of observation are country-occupation, $i j$, in each year t from 1998 to 2004 . The dependent variable is the log of the natives' employment rate at the country-occupation cell in a given year. The explanatory variable of interest is the log of the share of immigrants in the workforce of a country-occupation cell. The size of the workforce cell has been fixed to its 1998 value. Under all estimates we report in parenthesis heteroskedasticity robust standard errors clustered at the country occupation level. The instrumental variable is the shift share instrument computed using the Altonji and Card (1991) method.

$* * * p<0.01, * * p<0.05, * p<0.1$ 
factor is technological change that fosters relative demand for some occupations, in all sectors, in which immigrants may be flowing. We then turn to IV estimates, presented in the three last columns of tables 1 and 2. First stage results for these estimations are presented in the lower panel of table 1. Not surprisingly, as already suggested by figure 2, the coefficient associated with the IV is highly significant and positive. Partial $R^{2}$ is also high, given that the set of fixed effects included catches a lot of heterogeneity across local labor markets. Therefore the initial origin country distribution of immigrants across local labor markets and the subsequent flows by origin country into the whole OECD are a strong predictor of immigrants' share changes within local labor markets.

The IV estimates suggest a small but positive, causal effect of immigration on male native's employment rate : doubling the share of immigrants within an occupation rises native's employment rate within that occupation by $2 \%$. Reassuringly, and comforting the exogeneity of our instrument, this estimate is robust to the introduction of the industry labor demand shift. Although small, it is important to note that the share of immigrants in most occupations has more than doubled over our sample period, suggesting that the employment creation effect of immigrants, over this short period of time, may have been substantial. ${ }^{26}$

In table 2 (and in columns (4), (5) and (6) of table 7 in appendix 9), we run the same set of regressions for our sample of female workers. The coefficient for the share of immigrants is statistically non different from zero once we control for local labor market specific fixed effects for all estimation methods. Consistently with our theoretical model, a tentative interpretation of this disparity of results between male and female is that outside opportunities are closer for immigrant and native females than they are for immigrant and native males.

\subsection{Displacement effects within local labor markets}

We turn now to the estimation results for the effect of immigrants on natives' displacement within local labor markets. We present in table 3 the OLS and IV estimations of equation (22) for men.

\footnotetext{
${ }^{26}$ Contrasting results obtained from OLS and IV estimations provide interesting information about potential sources of bias. On the one hand, OLS estimates get very close to IV estimates only once country-occupation fixed effect are introduced in the estimates (Appendix 9). On the other hand, the fact that IV estimates are robust to all source of local labor market heterogeneity accounted for by our fixed effects and labor demand shift index comforts our exclusion restriction. Both results suggest that most of OLS estimates biases are due to the sorting of immigrants across local labor markets correlated with non time varying determinant of the natives' employment rate within local labor markets.
} 
OLS estimates suggest a significant outward displacement. However, this effect disappears once we control for unobserved endeogeneity bias with IV estimations. First stage coefficients of our instrument are fairly strong in all specifications, pointing out that past distribution of immigrants by origin countries across host countries, industries and occupations is a good predictor of actual flows across these different labor markets.

IV estimates, in columns 4 to 6 , clearly point towards an inward displacement. Coefficients are significantly different from unity in all specifications adopted. These results suggest that following an inflow of immigrants, occupational employment is getting more than proportionally concentrated into immigrants' receiving sectors: there has been an inward displacement of natives from other sectors or from unemployment into those sectors. Contrary to OLS, IV estimates are remarkably stable across various specifications of non observable heterogeneity (fixed effects).

These results provide some evidence on the fact that immigrants do not induce natives to reallocate towards other sectors (there is never an outward displacement). Instead, we observe an inward displacement which is consistent with a positive employment effect at the overall local labor market. More precisely, this labor reallocation is observed together with an increase in natives' employment rate within occupations. As a consequence we deduce that labor flows concern both, already employed natives but also previously unemployed natives, otherwise there would not be net employment creation. Given that estimated coefficients on the displacement effect are more than 3 times larger than those estimated on employment at the occupation level, flows from and into employment ought to be more important than flows from unemployment into employment. One assumption we postulate in the two sectors extension of our search and matching model to explain mobility of already employed natives across sectors is that immigrants may be primarily flowing towards more productive sectors paying higher wages.

The result is also interesting in light of the importance of structural unemployment in most European countries and shares some similarities with the idea initially suggested by Borjas (2001) according to which immigrants "grease the wheel of labor markets". For the author, immigrants are more likely to be the marginal worker whose location choices arbitrage spatial wage differences, thus increasing the efficiency of labor allocation. Instead, our argument is that immigrants affect the equilibrium rate of employment for natives due to their lower outside options. Given the importance of this assumption for interpreting our results, we devote the rest of the paper to the investigation of further results supporting the idea of a lower outside 
Table 3: The inward displacement within occupations. Male sample 1998-2004

\begin{tabular}{|c|c|c|c|c|c|c|}
\hline \multirow[t]{3}{*}{ Dependent variable: } & \multicolumn{6}{|c|}{ Log(employment sector $j$ occupation $o /$ total employment in $o$ ) } \\
\hline & & OLS & & & IV & \\
\hline & (1) & $(2)$ & $(3)$ & $(4)$ & $(5)$ & $(6)$ \\
\hline \multicolumn{7}{|l|}{ Independent Variables } \\
\hline $\begin{array}{l}\ln (\text { employed immigrants in sector } j \text { and } \\
\text { occupation } o \text { /employment in occupation } o)_{c t}\end{array}$ & $\begin{array}{c}0.751^{* * *} \\
(0.022)\end{array}$ & $\begin{array}{c}0.765^{* * *} \\
(0.022)\end{array}$ & $\begin{array}{c}0.811^{* * *} \\
(0.022)\end{array}$ & $\begin{array}{c}1.097^{* * *} \\
(0.036)\end{array}$ & $\begin{array}{c}1.097^{* * *} \\
(0.035)\end{array}$ & $\begin{array}{l}1.075^{* *} \\
(0.033)\end{array}$ \\
\hline Coefficient for IV in first stage & & & & $\begin{array}{c}0.862 \\
(0.035)\end{array}$ & $\begin{array}{c}0.864 \\
(0.036)\end{array}$ & $\begin{array}{c}0.881 \\
(0.035)\end{array}$ \\
\hline Partial R2 for first stage & & & & 0.54 & 0.55 & 0.62 \\
\hline $\begin{array}{l}\text { Additional Fixed Effects } \\
\text { country by occupation by year }\end{array}$ & no & yes & yes & no & yes & yes \\
\hline country by sector by year & no & no & yes & no & no & yes \\
\hline Observations & 2,446 & 2,446 & 2,446 & 2,446 & 2,446 & 2,446 \\
\hline
\end{tabular}

Units of observation are at the sector-occupation-country level, joc, in each year $t$ from 1998 to 2004 . The dependent variable is the log ratio of employed in a sector and occupation to the total employment of an occupation, in each country $c$ and year $t$ from 1998 to 2004 . The explanatory variable of interest is the log ratio of immigrants employment in an occupation and sector to the total employment of an occupation in each country $c$ and year $t$ from 1998 to 2004 . In all regressions we include country by year, country by sector and country by occupation fixed effects. Under all estimates we report in parenthesis heteroskedasticity robust standard errors clustered at the country, occupation and sector level. The instrumental variable is the shift share instrument computed using a variant of the Altonji and Card (1991) method.

The coefficient is statistically different from 1 at: $* * * p<0.01, * * p<0.05$

option for immigrants.

\section{How relevant is our mechanism?}

In this section we provide some evidence that the lower reservation wage of immigrants is a plausible mechanism for explaining the short-run positive impact of immigrants on natives' employment rate. The model outlined above suggests that certain conditions must hold for this to happen. In particular, everything else equal, immigrants with relatively higher values of outside option should have lower impact on natives' employment. Therefore, we can exploit the fact that the outside option varies across various groups of immigrants to gauge the relevance of our mechanism. We emphasize first differences across immigrants with respect to their duration of residence and their country of origin. Next, we exploit institutional heterogeneity across countries, promoting diverging outside option gaps between natives and immigrants. 


\subsection{Distinguishing new immigrants from long term stayers}

Our baseline equation (19) does not distinguish between veterans and earlier immigrants which amounts assuming that all immigrants have the same outside options. This is unlikely to be the case. As suggested by Chiswick (1978), Borjas (1994) or Borjas (1999) for the US, Chiswick, Lee, and Miller (2005) for Australia, Friedberg and Hunt (1995) for Israel or Lam and Liu (2002) for Hong Kong, with years of residence, immigrants' wages converge to that of natives. The implicit idea in these papers is that immigrant workers acquire language skills and other productive assets making them closer substitutes to natives. Our working hypothesis on the divergence of outside options (reservation wage) between natives and immigrants, provides another rationale to this empirical finding. With years of residence in the host country, immigrants become eligible to the unemployment benefit, they develop their social networks and get a better knowledge of the labor market. Therefore, the value of their outside option should converge to that of natives, and their positive impact on the native's employment rate should be lower.

To relax the assumption of identical outside options we distinguish, within an occupation, immigrants with less than 10 years of residence (low outside option group) from those with more than 10 years (high outside option group). In a way, if immigrants assimilate, their outside option rises over time, converging to that of natives. As immigrants become more substitutable with natives with respect to their profitability for employers, incentives to open more vacancies decrease and their positive impact on native's employment rate should vanish.

Let shim $_{o c t 1}$ be the ratio of immigrants with less than or equal to 10 years of residence in occupation o, country c and year t, to the total population of the cell in 1998 and let shim oct $2_{2}$ be the same ratio for immigrants with more than 10 years of residence. ${ }^{27}$ The equation to be estimated becomes then:

$$
\begin{aligned}
\ln y_{o c t}= & \gamma_{0}+\gamma_{1} * \ln \left(\operatorname{shim}_{\text {oct } 1}\right)+\gamma_{2} * \ln \left(\text { shim }_{\text {oct } 2}\right)+ \\
& \mu_{o t}+\alpha_{o c}+u_{o c t}
\end{aligned}
$$

This specification assumes a piecewise linear impact of immigrants on local labor market that depends on their years of residence within a host country labor market. Under the outside-option assimilation hypothesis, our testable assumption becomes $\gamma_{1}>\gamma_{2}$.

\footnotetext{
${ }^{27}$ The choice of tenure spells in host countries is a trade-off between having a sufficient number of observations within each cell and a sufficient variation to allow for identification. The EU-LFS survey does not code residence levels above 10 years.
} 
Since we face the same identification issues as in equation (19), we use as an additional instrument an immigrants' specific labor demand shift index. We exploit the fact that sectoral labor demand shocks at the national level, such as those considered in the construction of the labor demand shift index, may have differential impact on immigrants' sorting across occupations due to the past distribution of immigrants' occupational employment across sectors. This new instrument hinges on the strength of immigrants' networks at the occupation level that are more or less effective depending on sectoral labor demand shocks. For instance, assume that immigrants working in "Elementary occupations" in France were highly concentrated in the "Hotel \& Restaurant sector" in 1990. Assume that this sector experiences a positive shock in a certain period of time between 1998 and 2004. We expect the share of immigrants in elementary occupations to increase relatively more than in other occupations, due to network effects and the fact that "Hotel \& Restaurant sector" is a large employer of workers in "Elementary occupations". Thus our instrument generalizes the labor demand shift index, but uses as fixed weight the past distribution of immigrants within occupations across sectors. To be specific, let $\tilde{\gamma}_{o c k, 1990}$ denote the share of immigrants in occupation $o$ working in sector $k$ in country $c$ in 1990, then our second instrument is:

$$
(\text { Demand shift })_{\text {oct }}^{\text {immigrants }}=\sum_{k} \tilde{\gamma}_{o c k, 1990} Y_{c k t}
$$

where, as before, $Y_{c k t}$ denotes the two digit real industrial output in sector $k$. Our identification assumption is the following: immigrants will be differently attracted into occupations due to (i) their past distribution across sectors within an occupation and (ii) due to sectoral output shocks at the national level. Our identification assumption relies on the exogeneity of past immigrants distribution across sectors and occupations.

In a way, our instrument is the predicted employment change of immigrants within occupations due to between-sector demand shifts and the past distribution of immigrants' occupational employment across sectors. To make sure that this instrument is not correlated with the contemporaneous distribution of natives across occupations due to sectoral labor demand shock, we take care to control in all our IV regressions for the (log of) labor demand shift index (Demand shift $)_{\text {oct }}$. This should control for the direct effect of sectoral labor demand shift on natives' occupational employment. Thus our identification relies only on the differential impact of these shocks on immigrants because of their historical distribution within occupations across sectors. Table 4 presents the OLS and the IV (equation 23) estimates for the impact of the share 
of veteran immigrants (more than 10 years of residence) and new immigrants (less than 10 years) in an occupation for men. For both estimation methods, OLS and IV, the share of recent immigrants exerts a small but positive impact on natives' employment rate. The impact of changes in the share of veteran immigrants is much smaller and non statistically different from zero in IV estimations. Our instruments are less strongly correlated with changes in veteran immigrants than with changes in recent immigrants. This is an expected result as these instruments are more suitable for changes in immigrants' flows.

Endogeneity issues for veteran immigrants should be of lesser relevance. Indeed, changes in their share are unlikely to be correlated with contemporaneous local labor market flows. Moreover, results from table 1 suggest that most of the bias is eliminated once we control for non-time varying local labor market specific employment rate. In column (3) of table 4 we omit the share of veteran immigrants and obtain a similar results with a much stronger first stage. Overall, doubling the share of recently arrived immigrants in an occupation increases the employment rate of natives by $1,5 \%$.

According to our model, these results are consistent with the view that new immigrants have lower outside opportunities as compared to natives and that differences in outside option gaps disappear over time as immigrants assimilate with respect to their outside option opportunities. Therefore, changes in the share of recent immigrants within an occupation decrease the average wage paid by firms in that occupation, triggering the opening of more vacancies and leading to higher employment rate for natives. This positive externality disappears as immigrants outside opportunity converges to that of natives.

\subsection{Immigrants from EU-15 vs. immigrants from outside EU-15}

Disparities in outside options among immigrants can also be related to their country of origin. Immigrants from EU in particular may have a closer outside option to natives than immigrants from outside EU. ${ }^{28}$ If this is the case the positive impact on native employment should be larger when considering non EU15 immigrants, who are likely to accept a lower wage than EU15 immigrants, and who are thus more profitable.

Within occupations, we now distinguish between immigrants from EU15 and immigrants from

\footnotetext{
${ }^{28}$ Immigrants from EU15 face, on average, lower migration costs and are more freely to move back and forth to their home countries. Although limited, several EU15 countries have agreements regarding the international portability of work benefits that workers are entitled to.
} 
outside EU15. Since some countries do not report this distinction, some observations are lost. Let shim octEU15 $_{15}$ be the ratio of immigrants coming from EU15 countries, to the 1998 population

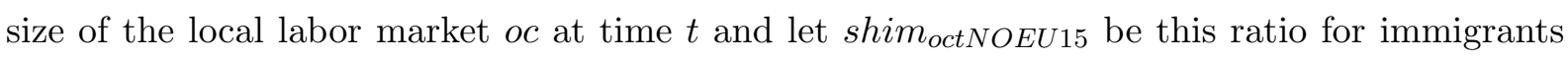
coming from outside EU15. The equation to be estimated becomes then:

$$
\begin{aligned}
\ln y_{\text {oct }}= & \gamma_{0}+\gamma_{1} * \ln \left(\operatorname{shim}_{\text {oct NOEU15 }}\right)+\gamma_{2} * \ln \left(\operatorname{shim}_{\text {oct } E U 15}\right)+ \\
& +\mu_{\text {ot }}+\alpha_{o c}+u_{\text {oct }}
\end{aligned}
$$

Under the hypothesis that the outside option of immigrants from outside EU15 is lower than that of EU15 immigrants, we should find $\gamma_{1}>\gamma_{2}$.

We face the same identification issues as in equation (19). We use shift share instruments based on immigrants past labor network across occupations and countries. Each shift share instrument is computed separately for EU15 and non EU15 immigrants in equation (21) when it comes to aggregate over origin countries.

Results for men are presented in table 4 for the OLS and the IV. The share of non EU15 immigrants exerts in both estimation methods a positive, statistically significant and larger impact than what found previously on natives' employment rate: doubling the share of non EU15 immigrants in an occupation, increases the employment rate of natives by $5 \%$ in the IV estimation. Instead, immigrants coming from EU15 exert a comparatively very small impact which becomes non-significantly different from zero once estimated with IV. Considering only changes in non EU15 immigrants in the last column increases the strength of our instrument but does not alter the result. Thus we confirm that immigrants may have differential impact on natives depending on characteristics that potentially affect their outside option with respect to natives.

\subsection{Heterogeneity across country}

Up to now we have shown that immigrants with different durations of residence in the host country and with different origin backgrounds have different impact on natives' employment rate. We postulate that this differential impact reflects different outside option gaps among immigrants.

We now explore heterogeneity across destination countries with respect to institutional characteristics that may affect outside option gaps of immigrants with respect to natives. In the model the outside gap reflects, essentially, the differential eligibility to unemployment benefit. 
Table 4: Heterogeneity among immigrants with different duration of residence and from different origin countries. Male sample.

Dependent variable: $\log ($ employment rate of natives)

\begin{tabular}{|c|c|c|c|c|c|c|}
\hline Estimation method & OLS & IV & IV & OLS & IV & IV \\
\hline Independent Variables & \multirow{5}{*}{$\begin{array}{c}0.010^{* * *} \\
(0.003) \\
0.006^{*} \\
(0.004)\end{array}$} & \multirow{5}{*}{$\begin{array}{c}0.015^{* * *} \\
(0.005) \\
-0.006 \\
(0.017)\end{array}$} & \multirow{5}{*}{$\begin{array}{c}0.014^{* * *} \\
(0.005)\end{array}$} & & & \multirow{5}{*}{$\begin{array}{c}0.049^{* * * *} \\
(0.011)\end{array}$} \\
\hline $\ln (\text { New immigrants/workforce 1998) })_{\text {oct }}$ & & & & & & \\
\hline $\ln$ (Veteran immigrants/workforce 1998) oct & & & & & & \\
\hline $\ln$ (Non EU15 immigrants/workforce 1998) oct & & & & $\begin{array}{c}0.020^{* * *} \\
(0.005)\end{array}$ & $\begin{array}{c}0.053^{* * *} \\
(0.014)\end{array}$ & \\
\hline $\ln$ (EU15 immigrants/workforce 1998) $)_{\text {oct }}$ & & & & $\begin{array}{c}-0.007^{* *} \\
(0.003)\end{array}$ & $\begin{array}{l}-0.008 \\
(0.024)\end{array}$ & \\
\hline First Stage F test of excluded instruments & & \multirow{5}{*}{$\begin{array}{c}22.07 \\
4.27\end{array}$} & \multirow{5}{*}{39.58} & & & \multirow{5}{*}{17.12} \\
\hline $\ln (\text { New immigrants/workforce 1998) })_{\text {oct }}$ & & & & & & \\
\hline $\ln$ (Veteran immigrants/workforce 1998) oct & & & & & & \\
\hline $\ln$ (Non EU15 immigrants/workforce 1998) oct & & & & & 8.94 & \\
\hline $\ln ($ EU15 immigrants/workforce 1998) oct & & & & & 11.13 & \\
\hline \multicolumn{4}{|l|}{ Fixed Effects } & & & \\
\hline year by occupation & yes & yes & yes & yes & yes & yes \\
\hline country by occupation & yes & yes & yes & yes & yes & yes \\
\hline Observations & 600 & 600 & 600 & 522 & 522 & 522 \\
\hline
\end{tabular}

Units of observation are country-occupation cells, oc, in each year $t$ from 1998 to 2004. The dependent variable is the log share of employed natives in the country-occupation cell in a given year. The explanatory variable of interest is the log of the share of immigrants in the workforce of a country-occupation cell in a given year. The size of the workforce cell has been fixed to its 1998 value. Under all estimates we report in parenthesis heteroskedasticity robust standard errors clustered at the country occupation level. All regressions control for the labor demand shift index. Instrumental variables in column (2) are the shift share instrument computed using a variant of the Altonji and Card (1991) method, and the instrument (Demand shift) for immigrants is computed according to equation (24). In column 3, veteran immigrants are dropped from the estimation and we use only the shift share instrument. In column 6 we omit the share of EU15 immigrants from the estimation and use the share of NOEU15 immigrants predicted by the shift share variable as instrument.

$* * * p<0.01, * * p<0.05, * p<0.1$ 
This is, in particular, related to the fact that immigrants have lower host country labor market experience and that most countries ask for a minimum work experience in order to become eligible to unemployment benefits. If this is the case, conditional on being unemployed, immigrants take-up rate of unemployment benefit should be lower than that of natives. We then use as a "proxy" for the outside-option gap between immigrants and natives, the ratio of natives to immigrants take-up rates for similar natives and immigrants.

Giuletti et al. (2011) have recently computed such conditional take-up rate for countries in our sample. The authors note that, while immigrants have higher unconditional probability of receiving unemployment benefits, this is not anymore the case once we condition on unemployment status and socioeconomic characteristic. Instead, if anything, immigrants are less likely to be unemployment benefit recipients. Consistently with our previous results, this is particularly true for those from non-EU origins. Using their results we estimate the following relation which extends our benchmark equation by introducing the ratio of native to immigrant conditional take-up rate and uses it as a proxy for heterogeneity in native-immigrants outside gap across countries.

$$
\ln y_{o c t}=\beta_{0}+\beta_{1} * \ln \operatorname{shim}_{o c t}+\beta_{2} * T U R_{c} * \ln \operatorname{shim}_{o c t}+\alpha_{o c}+\alpha_{o t}+u_{o c t}
$$

where the unemployment benefit take up rate ratio, $T U R$, is computed as:

Natives conditional take up rate

\section{Non EU15 immigrants conditional take-up rate}

This ratio is computed for each country, using data from the EU-SILC survey in year 1999. ${ }^{29}$ We are only interested in the differential effect of immigrants on native's employment rate along the immigrants-natives outside-option gap across host countries. Therefore, we leave the direct effect of divergent institutions across countries to be absorbed by the country fixed effect included in our regressions. We then focus on the interacted term between the TUR and the share of immigrants in a particular local labor market $o c$ in year $t$. So we capture the differential impact of immigrants on native's employment rate across destination countries due to differences in conditional take-up rates between natives and immigrants across countries.

Alternatively, we also create the dummy variable DummyTUR that distinguishes countries in which the unemployment benefit take up rate ratio is above 1 (high outside option gap countries),

\footnotetext{
${ }^{29}$ We run a probit on a variable equal to one if the individual is an UB recipient against an immigration dummy controlling for age, age square, sex and education.
} 
from those where the ratio is below one (low outside option gap countries), and we run similar regressions. ${ }^{30}$

Results are reported in table 5. Columns (1) and (3) provide the OLS estimations while in columns (2) and (4) we correct for the endogeneity bias using instrumental variable estimation. As an additional instrument we simply use the take-up-ratio crossed with our previous shift share instrument. In all cases, we control for country by occupation and year by occupation fixed effects.

Results provided by columns (1) and (2) show that the positive impact of the share of immigrants on the native's employment rate increases with the conditional TUR. Moreover, as shown by columns (3) and (4) the impact of immigrants on natives' employment is positive and statistically significant only for countries in which the conditional immigrants' take-up rate is below that of natives (high outside option gap countries).

These results support the view that disparities in outside options, mediated by labor market institutions, are a potentially relevant channel along which immigrants exert their positive externality on natives' employment rate.

\section{$7 \quad$ Numerical simulations}

Is our model able to reproduce the empirically estimated causal impact of immigrants on natives' employment rate? We answer this question by numerically simulating our simple framework. More precisely, we simulate the impact of a $1 \%$ increase in the share of immigrants on natives' employment rate for different values of the gap between the outside option of natives and immigrants. For every value of the outside option gap we provide the elasticity of the natives' employment rate. We compare our simulated result with the empirically estimated causal effect. The numerical values of the parameters are summarized in table 6 . The discount factor, the recruiting cost and the bargaining power are taken from Mortensen and Pissarides (1994). As already detailed before, a matching function of the Cobb-Douglas form is assumed, where $\alpha$ is the elasticity with respect to job seekers and it is assumed to be equal to 0.5 (see Petrongolo and Pissarides (2001)). Concerning the exogenous job destruction rate, we use the estimations provided by Davis, Haltiwanger, and Schuh (1996) for the US or by the OECD (1996) for

\footnotetext{
${ }^{30}$ High outside option gap countries are Germany, Belgium, Portugal, France, Sweden, Ireland, Spain, Netherland. Low outside option gap countries comprise Italy, Denmark, Luxembourg, Norway, Austria and Finland. Data for Greece is not available.
} 
Table 5: Relevance of the divergent institutions across countries

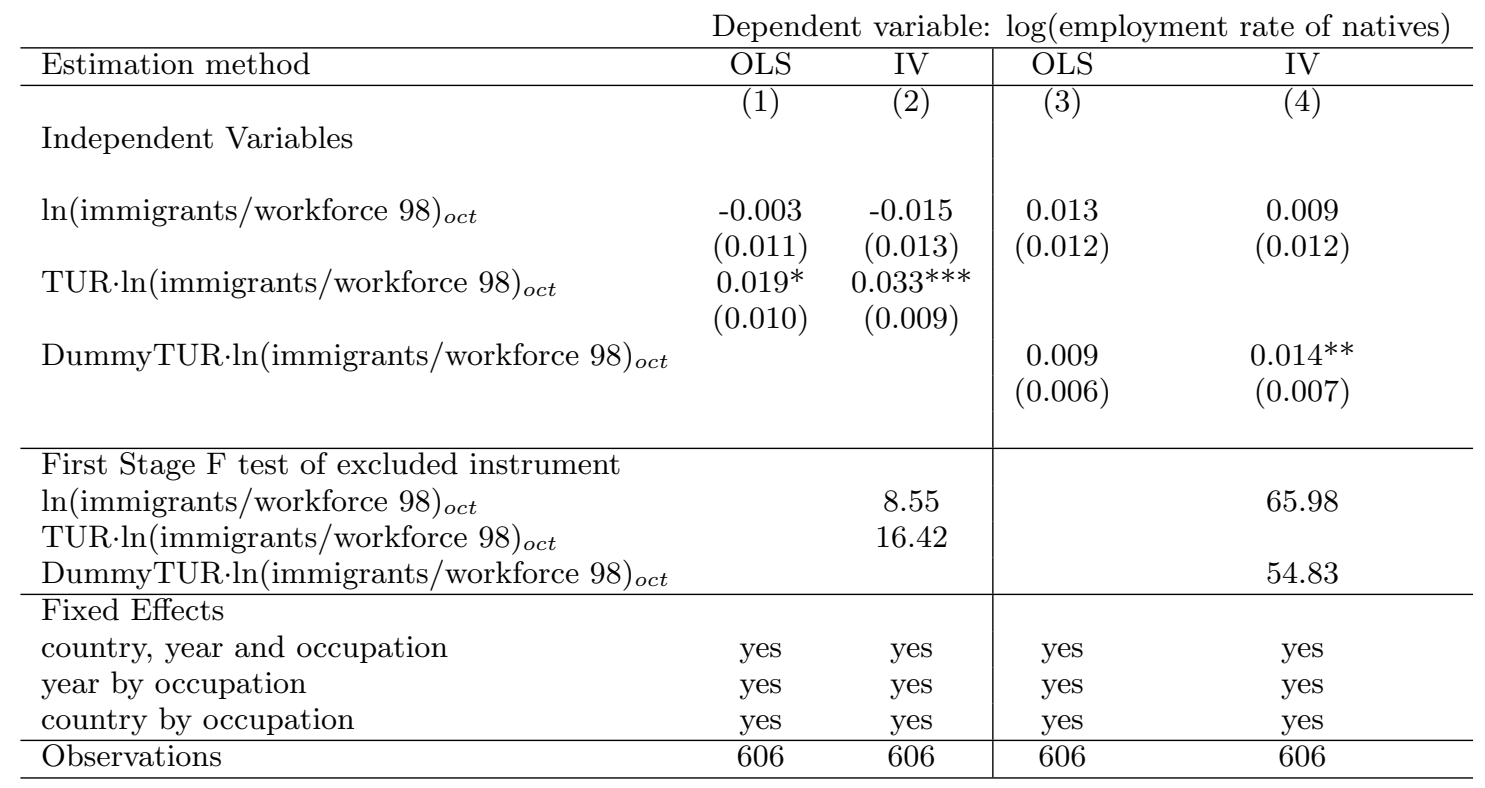

Units of observation are country-occupation, $i j$, in each year $t$ from 1998 to 2004 . The dependent variable is the log of the natives' employment rate in the country-occupation cell in a given year. The explanatory variable of interest is the log of the share of immigrants in the workforce of a country-occupation cell. The size of the workforce cell has been fixed to its 1998 value. Under all estimates we report in parenthesis heteroskedasticity robust standard errors clustered at the country occupation level. The instrumental variable is the shift share instrument computed using the Altonji and Card (1991) method.

$* * * p<0.01, * * p<0.05, * p<0.1$

Table 6: Baseline Parameters Values

\begin{tabular}{|c|c|c|c|}
\hline Job productivity & $h$ & $=$ & 1 \\
\hline Interest rate & $r$ & $=$ & .04 \\
\hline Matching elasticity & $\alpha$ & $=$ & 0.5 \\
\hline Matching efficiency & $m_{0}$ & $=$ & 0.4 \\
\hline Recruiting cost & $c$ & $=$ & $0.3 h$ \\
\hline Exogenous separation rate & $s$ & $=$ & 0.12 \\
\hline Bargaining power & $\eta$ & $=$ & 0.5 \\
\hline Outside option natives & $b$ & $=$ & 0.5 \\
\hline
\end{tabular}


other western countries and set $s$ at 0.12 . The outside option equals $b=0.5$. For simplicity, productivity is normalized to one. The scale parameter of the matching function $m_{0}$ is chosen so that the average unemployment rate of immigrants and natives is around $10-11 \%$.

Our aim is to determine the gap between the values of the outside option of natives and immigrants that allows us to reproduce the estimated elasticity of the native's employment rate with respect to the immigrants' share. According to our estimation of equation (19) (tables 1 and 2), a $1 \%$ increase in the immigrants share within an occupation, fosters a rise in the employment rate of natives around $0.02 \%(s e=0.008)$. When distinguishing among immigrants by years of residence in the host country (equation (23) table 4) the rise in the native's employment rate equals $0.014 \%(s e=0.005)$ and it is explained by recently arrived immigrants. When immigrants are differentiated by country of origin (equation (25) table 4), the impact is larger and rises to $0.053 \%(s e=0.014)$ and it comes from non-EU15 immigrants. Finally, when considering institutional heterogeneity across countries (equation (26) table 5) the impact equals $0.014 \%$ $(s e=0.007)$.

We define numerically our explicative variable as the ratio of immigrants in a particular occupation to the total workforce (native plus immigrant) in that occupation. We let this ratio vary by $1 \%$ and simulate changes in the employment rate of natives (in that occupation) as the ratio between outside opportunities of immigrants and natives varies. Figure 3 displays the main results. As observed, for all possible values of the ratio $b_{I} / b_{N}$, the simulated elasticity of native employment to immigrants labor supply shock falls within the confidence interval of our empirically estimated causal effects (IV estimates). Moreover, as far as the immigrant outside option represents $30 \%$ or less of that of natives, the impact on the native's employment rate lies between $0.014 \%$ and $0.02 \%$ which are our median interval points estimates. While we lack of a precise measure of this gap, our reading of the literature on immigrants-natives wage discrimination suggests that $30 \%$ gap is a reasonable value.

Overall, we view results from these simulations as further evidence that disparities in outside options between natives and immigrants, once included in a realistic functioning of the labor market, provide a plausible mechanism through which immigrants may enhance employment opportunities of natives. 


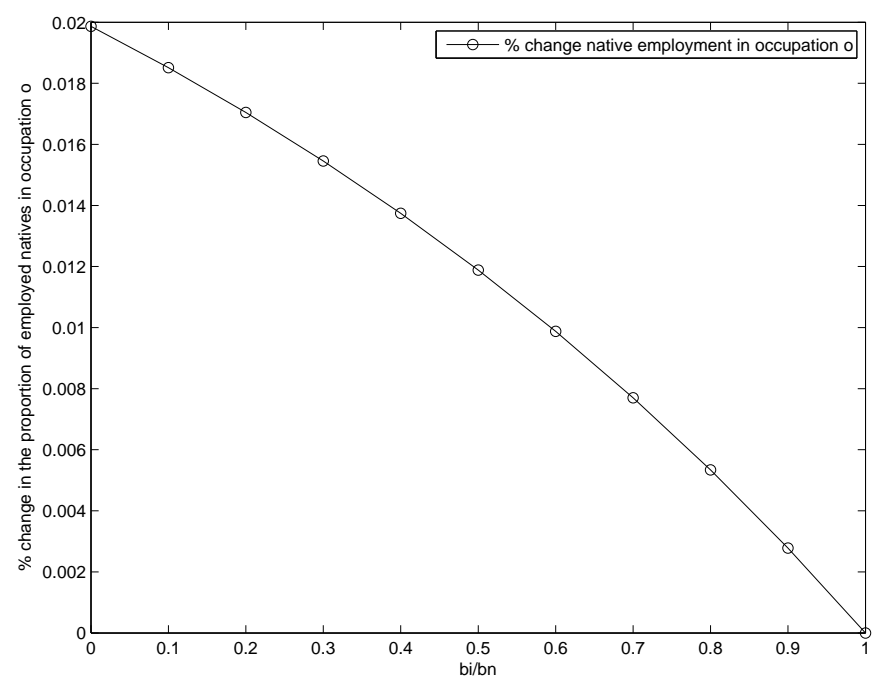

Figure 3: Percentage change in the proportion of employed natives in occupation $o$ when the proportion of immigrants in the total population of that occupation increases by $1 \%$.

\section{Conclusion}

The increasing contribution of immigrants to the labor force is among the most important contemporaneous labor supply shocks facing most developed countries. To date, most of the literature has discussed the labor market consequences of this shock using a standard neoclassical labor-supply labor-demand framework. However, this approach does not allow to introduce important differences in non productive assets between immigrants and natives.

We have shown in this paper that, once introduced into a frictional labor market, differences in host country specific assets between immigrants and natives can revert conclusions reached by the standard model: in the short run immigrants improve employment prospects of competing native workers. Thus, instead of crowding-out natives, immigrants may instead crowd-in natives in sectors and occupations in which they contribute.

The employment creation effect has been found more important for new immigrants, for immigrants from non-EU15 countries and for countries that display large differences in unemployment benefit take-up rate between similar immigrants and natives. Overall these results highlight that immigrants may lack of host country specific assets, which explains their positive impact on natives' employment. Some implications are worth pursuing further.

First, regarding the design of an optimal immigration policy. On the one hand, recent research indicates that skilled immigrants may crowd-out natives from skilled jobs (see Borjas (2009)). 
On the other hand, it has been argued that unskilled immigrants may improve incentives for natives to acquire human capital by rising the skill premium (see Hunt (2011)). In contrast, our conclusions suggest that host countries with more selective immigration policy could improve the employment rate of skilled workers and, at the same time, rise incentives for natives to acquire human capital. A welfare analysis of such policy is a natural extension of the model proposed in this paper.

Second, on the empirical side we highlight the importance of distinguishing immigrants according to their origin country or duration of residence. More generally, our more realistic approach to the functioning of the labor market stresses the importance of considering any heterogeneity between immigrants and natives that would affect their relative bargaining position with respect to employers.

\section{References}

Acemoglu, D. 2003. "Labor- and Capital-Augmenting Technical Change." Journal of European Economic Association 1:1-37.

Acemoglu, D., and D. Autor. 2011. Skills, Tasks and Technologies: Implications for Employment and Earnings (Handbook of Labor Economics ). Volume 4. Edited by Orley Ashenfelter and David E. Card. Elsevier.

Algan, Y., C. Dustman, A. Glitz, and A. Manning. 2010. "The Economic Situation of First and Second Generation Immigrants in France, Germany and UK." The Economic Journal 120 (542): 4-30.

Altonji, J., and D. Card. 1991. Immigration, Trade and Labor. Edited by J. Abowd and R. Freeman. University of Chicago Press.

Angrist, J., and A. Kugler. 2003. "Productive or counter-productive: labor market institutions and the effect of immigration on EU natives." Economic Journal 113 (488): 302-331.

Binmore, K., A. Rubinstein, and A. Wolinsky. 1986. "The Nash Bargaining Solution in Economic Modelling." Rand Journal of Economics 17 (2): 176-188.

Borjas, G. 1994. "The Economics of Immigration." Journal of Economic Literature XXXII (December): 1667-1717.

—. 1999. "Immigration and Welfare Magnets." Journal of Labor Economics, October. 
2001. "Does Immigration Grease the Wheels of the Labor Market?" Brookings Papers on Economic Activity 1:69-119.

—. 2003. "The Labor Demand Curve is Downward Sloping: Reexamining the Impact of Immigration on the Labor Market." Quarterly Journal of Economics 118 (4): 1335-1374 (November).

- 2009. Science and Engineering Careers in the United States. Edited by Richard B. Freeman and Daniel L. Goroff. University of Chicago Press.

Card, D. 1990. "The Impact of the Mariel Boatlift on the Miami Labor Market." Industrial and Labor Relations Review, vol. 43 (January).

—. 2001. "Immigrant Inflows, Native Outflows and the Local Labor Market Impacts of Higher Immigration." Journal of Labor Economics, vol. 19 (January).

- 2005. "Is the New Immigration Really So Bad?" Economic Journal, vol. 115 (November).

—. 2009. "Immigration and Inequality." American Economic Review 99 (2): 1-21.

Card, D., and J. DiNardo. 2000. "Do Immigrant Inflows Lead to Native Outflows?" The American Economic Review, Papers and Proceedings of the One Hundred Twelfth Annual Meeting of the American Economic Association 90 (2): 360-367.

Chassamboulli, A., and T. Palivos. 2014. "A Search-Equilibrium Approach to the Effects of Immigration on Labor Market Outcomes." International Economic Review 55 (1): 111-129.

Chassamboulli, A., and G. Peri. 2014. "The Labor Market Effects of Reducing Undocumented Immigrants." Mimeo.

Chiswick, R.B. 1978. "The Effects of Americanization on Foreign-Born Men." Journal of Political Economy 86:81-87.

Chiswick, R.B., Y. Lee, and P. Miller. 2005. "Immigrant Earnings: A Longitudinal Analysis." Review of Income and Wealth 51:485-503.

D’Amuri, F., and G. Peri. 2014. "Immigration, Jobs and Labor Market Institutions: Evidence from Europe." Journal of European Economic Association, vol. Forthcoming.

Davis, S.J., J.C. Haltiwanger, and S. Schuh. 1996. Job Creation and Destruction. MIT Press. Docquier, F., O. Lohest, and A. Marfouk. 2007. "Brain drain in developing countries." World Bank Economic Review 21:193-218. 
Dustmann, C., A. Glitz, and T. Frattini. 2008. "The Labour Market Impact of Immigration." Oxford Review of Economic Policy 24:477 - 494.

Friedberg, R., and J. Hunt. 1995. "The Impact of Immigration on Host Wages, Employment and Growth." Journal of Economic Perspectives IX:23-44.

Giuletti, C., M. Guzi, M Kahanec, and K.F. Zimmermann. 2011. "Unemployment Benefits and Immigration: Evidence from EU." IZA Discussion Paper, no. 6075.

Glitz, A. 2011. "The Labor Market Impact of Immigration: A Quasi-Experiment Exploiting Immigrant Location Rules in Germany." forthcoming Journal of Labor Economics.

Gonzalez, L., and F. Ortega. 2008. "How Do Very Open Economies Absorb Large Immigration Flows? Recent Evidence from Spanish Regions." IZA Working Paper, vol. 3311.

Hall, R., and P. Milgrom. 2008. "The Limited Influence of Unemployment on the Wage Bargain." American Economic Review 98 (4): 1653-1674 (September).

Hunt, J. 2011. "Which Immigrants Are Most Innovative and Entrepreneurial? Distinctions by Entry Visa." Journal of Labor Economics, July.

Katz, L., and O. Blanchard. 1992. "Regional Evolutions." Brookings Papers on Economic Activity 1:1-75.

Katz, L., and K. Murphy. 1992. "Changes in Relative Wages, 1963-1987: Supply and Demand Factors." Quarterly Journal of Economics 107 ((February): 35-78.

Kee, P. 1995. "Native-Immigrant Wage Differentials in the Netherlands: Discrimination?" Oxford Economic Papers 47 (2): 302-317 (April).

Lam, K.C., and P.W. Liu. 2002. "Earnings Divergenceof Immigrants." Journal of Labor Economics 20:86-101.

Lewis, E. 2011. "Immigration, Skill Mix, and Capital-Skill Complementarity." Quarterly Journal of Economics 126 (2): 1029-1069.

Liu, X. 2010. "On the Macroeconomic and Welfare Effects of Illegal Immigration." Journal of Economic Dynamics and Control 34:2547-2567.

Longhi, S., P. Nijkamp, and J. Poot. 2006. "The Impact of Immigration on the Employment of Natives in Regional Labour Markets: A Meta-Analysis." ISER Working Paper, vol. 2006-10. 
Mortensen, D., and E. Nagypal. 2007. "More on Unemployment and Vacancy Fluctuations." Review of Economic Dynamics 10 (3): 327-347.

Mortensen, D., and C.A. Pissarides. 1994. "Job Creation and Job Destruction in the Theory of Unemployment." Review of Economic Studies 61:397-415.

Munshi, K. 2003. "Networks In The Modern Economy: Mexican Migrants In The U.S. Labor Market." The Quarterly Journal of Economics 118 (2): 549-599 (May).

Nagypal, E. 2007. "Labor Market Fluctuations, On-the-Job Search and the Acceptance Curse." Mimeo.

Nanos, P., and C. Schluter. 2012. "The composition of Wage Differentials between Migrants and Natives." University of Southampton Discussion Paper, no. 1214.

OECD. 1996. Job Creation and loss: analysis, policy and data development. OECD.

Ortega, J. 2000. "Pareto-Improving Immigration in an Economy with Equilibrium Unemployment." Economic Journal 110 (460): 92-112 (January).

Ortega, J., and G. Verdugo. 2011. "Immigration and the Occupational Choice of Natives: A Factor Proportions Approach." IZA Working Paper, vol. 5451.

Ottaviano, G., and G. Peri. 2012. "Rethinking the Effects of Immigration on Wages." Journal of the European Economic Association 10 (1): 152-197.

Peri, G., and C. Sparber. 2011. "Highly-Educated Immigrants and Native Occupational Choice." Industrial Relations 50, no. 3 (July).

Petrongolo, B., and C. Pissarides. 2001. "Looking Back into the Black Box: a Survey of the Matching Function." Journal of Economic Literature 39:390-431.

Pissarides, C. 1990. Equilibrium Unemployment Theory. Edited by MIT Press. Cambridge, Massachusetts: MIT Press.

Pissarides, C., and G. Vallanti. 2007. "The impact of TFP growth on steady-state unemployment." International Economic Review 48 (May): 607-640.

Smith, C. 2012. "The Impact of Low-Skilled Immigration on the Youth Labor Market." Journal of Labor Economics 30 (1): 55-89. 
Table 7: The dependent variable is the log ratio of the natives' employment rate

\begin{tabular}{|c|c|c|c|c|c|c|}
\hline \multirow[t]{2}{*}{ Specification sample } & \multicolumn{3}{|c|}{ Males } & \multicolumn{3}{|c|}{ Females } \\
\hline & $(1)$ & $(2)$ & $(3)$ & $(4)$ & $(5)$ & $(6)$ \\
\hline \multicolumn{7}{|l|}{ Independent Variable } \\
\hline $\ln$ (immigrants/workforce 98$)_{\text {oct }}$ & $\begin{array}{l}-0.005 \\
(0.006)\end{array}$ & $\begin{array}{l}-0.008 \\
(0.006)\end{array}$ & $\begin{array}{c}0.014^{* * *} \\
(0.004)\end{array}$ & $\begin{array}{c}-0.016 \\
(0.010)\end{array}$ & $\begin{array}{c}-0.021^{* *} \\
(0.009)\end{array}$ & $\begin{array}{l}-0.003 \\
(0.006)\end{array}$ \\
\hline \multicolumn{6}{|l|}{ Fixed Effects } & yes \\
\hline country by occupation & no & no & yes & no & no & yes \\
\hline Observations & 654 & 654 & 654 & 654 & 654 & 654 \\
\hline
\end{tabular}

Units of observations are country-occupation, $c o$, in each year $t$ from 1998 to 2004. The dependent variable is the log share of employed natives in the country-occupation cell in a given year. The explanatory variable of interest is the log of the share of immigrants in the workforce of a country-occupation cell in a given year. The size of the workforce cell has been fixed to its 1998 value. Under all estimates we report in parenthesis heteroskedasticity robust standard errors clustered at the country occupation level.

$* * * p<0.01, * * p<0.05, * p<0.1$

\section{Appendix: Estimation results}

\section{Appendix: A two-sector model}

\subsection{The matching process}

We consider a local labor market represented by occupation $i$. This occupation covers two sectors A and B. We assume that productivity in sector A is higher so wages earned by people employed in sector A are also higher. We assume that unemployed people in sector A have a per period probability $\lambda$ of being depreciated to sector B. We allow workers employed in sector B to do on-the-job search in sector A where wages are higher. Since we are considering a single occupation, these flows between sectors within an occupation are perfectly reasonable.

Let us denote as $t=A, B$ the two existing sectors, $j=N, I$ native and immigrant workers, $v^{t}$ the number of vacancies in sector $t, u_{j}^{t}$ the number of job seekers, $n_{j}^{t}$ the number of employed and $e o_{j}$ the on-the-job search effort. The matching functions can be thus written as: $M^{A}=m^{A}\left(v^{A}, u_{N}^{A}+\right.$ $\left.u_{I}^{A}+e o_{N} \cdot n_{N}^{B}+e o_{I} \cdot n_{I}^{B}\right)$ and $M^{B}=m^{B}\left(v^{B}, u_{N}^{B}+u_{I}^{B}+\lambda u_{N}^{A}+\lambda u_{I}^{A}\right)$. We assume a standard homogeneous matching function of the form $M^{A}=m_{0}\left(v^{A}\right)^{1 / 2}\left(u_{N}^{A}+u_{I}^{A}+e o_{N} \cdot n_{N}^{B}+e o_{I} \cdot n_{I}^{B}\right)^{1 / 2}$ and $M^{B}=m_{0}\left(v^{B}\right)^{1 / 2}\left(u_{N}^{B}+u_{I}^{B}+\lambda u_{N}^{A}+\lambda u_{I}^{A}\right)^{1 / 2}$.

Labor market opportunities are described by the market tightness variables $\theta^{A}=v^{A} /\left(u_{N}^{A}+\right.$ $\left.u_{I}^{A}+e o_{N} \cdot n_{N}^{B}+e o_{I} \cdot n_{I}^{B}\right)$ and $\theta^{B}=v^{B} /\left(u_{N}^{B}+u_{I}^{B}+\lambda u_{N}^{A}+\lambda u_{I}^{A}\right)$. The probability of filling 
an empty vacancy equals $q\left(\theta^{t}\right)=M^{t} / v^{t}$. The probability of finding a job is given by $p\left(\theta^{A}\right)=$ $M^{A} /\left(u_{N}^{A}+u_{I}^{A}+e o_{N} \cdot n_{N}^{B}+e o_{I} \cdot n_{I}^{B}\right)$ and $\left.p\left(\theta^{B}\right)=M^{B} /\left(u_{N}^{B}+u_{I}^{B}+\lambda u_{N}^{A}+\lambda u_{I}^{A}\right)\right)$. In sector A, a vacancy is filled by a native worker with probability $q\left(\theta^{A}\right) \frac{u_{N}^{A}+e o_{N} \cdot n_{N}^{B}}{u_{N}^{A}+u_{I}^{A}+e o_{N} \cdot n_{N}^{B}+e o_{I} \cdot n_{I}^{B}}$ and by an immigrant with probability $q\left(\theta^{A}\right) \frac{u_{I}^{A}+e o_{I} \cdot n_{I}^{B}}{u_{N}^{A}+u_{I}^{A}+e o_{N} \cdot n_{N}^{B}+e o_{I} \cdot n_{I}^{B}}$. In sector B, the probability equals $q\left(\theta^{B}\right) \frac{u_{N}^{B}}{u_{N}^{B}+u_{I}^{B}+\lambda u_{N}^{A}+\lambda u_{I}^{A}}$ for natives and $q\left(\theta^{B}\right) \frac{u_{I}^{B}}{u_{N}^{B}+u_{I}^{B}+\lambda u_{N}^{A}+\lambda u_{I}^{A}}$ for immigrants.

\subsection{The agents' behavior}

\subsubsection{Workers}

Employed workers coming from unemployed are paid $w_{j}^{t}$ whereas workers in sector A that were previously employed in sector B earn $w_{j}^{A B}$, for $j=N, I$. Jobs are destroyed at the exogenous probability $s$. Workers employed in sector B have a probability $e o_{j} \cdot p\left(\theta^{A}\right)$ of finding a job in sector A but they bear a disutility cost linked to the search effort equal to $\tau\left(e o_{j}\right)=\phi_{0} \cdot e o_{j}^{\phi_{1}}$, where $\phi_{1}>1$ so that $\tau^{\prime}\left(e o_{j}\right)>0$ and $\tau^{\prime \prime}\left(e o_{j}\right)>0$.

The asset values of employment in sector A, B and in sector A but from someone coming from $\mathrm{B}$, are respectively given by:

$$
\begin{aligned}
r E_{j}^{A} & =w_{j}^{A}+s\left(U_{j}^{A}-E_{j}^{A}\right) \\
r E_{j}^{B} & =w_{j}^{B}-\tau\left(e o_{j}\right)+s\left(U_{j}^{B}-E_{j}^{B}\right)+e o_{j} \cdot p\left(\theta^{A}\right)\left(E_{j}^{A B}-E_{j}^{B}\right) \\
r E_{j}^{A B} & =w_{j}^{A B}+s\left(U_{j}^{A}-E_{j}^{A B}\right)
\end{aligned}
$$

where $U_{j}^{t}$ stands for the asset values of unemployment.

The asset values of unemployment write as follows:

$$
\begin{aligned}
& r U_{j}^{A}=b_{j}+p\left(\theta^{A}\right)\left(E_{j}^{A}-U_{j}^{A}\right)+\lambda\left(U_{j}^{B}-U_{j}^{A}\right) \\
& r U_{j}^{B}=b_{j}+p\left(\theta^{B}\right)\left(E_{j}^{B}-U_{j}^{B}\right)
\end{aligned}
$$

where $b_{N}>b_{I}$.

The individual employed in sector B, searches on-the-job until all possible rents are exhausted, that is, until the marginal cost of an additional unit of search effort equals the marginal expected benefit from on-the-job search:

$$
\tau^{\prime}\left(e o_{j}\right)=p\left(\theta^{A}\right)\left(E_{j}^{A B}-E_{j}^{B}\right)
$$

Because $\tau^{\prime \prime}\left(e o_{j}\right)>0$ we deduce that an increase in $p\left(\theta^{A}\right)$ should push up on-the-job-search effort. Intuitively, if employment opportunities are improved in sector A, while wages in both sectors remain unchanged, individuals will search more intensively in sector A. 


\subsubsection{Firms}

From the firm's point of view, the asset value associated with an empty vacancy is given by minus the cost associated with the announcement of this vacancy, $\gamma$, plus the surplus obtained by the firm if it manages to fill the vacancy with a native worker or with an immigrant. The value of an empty vacancy in sector B is given by:

$$
r V^{B}=-\gamma+q\left(\theta^{B}\right)\left(\overline{J^{B}}-V^{B}\right)
$$

where $\overline{J^{B}}$ represents the average value of a filled vacancy. The value of a filled vacancy is defined by the instantaneous profit $h^{B}-w_{j}^{B}$ associated with the job (productivity minus the wage) plus the expected loss if the vacancy becomes empty, either because of an exogenous job destruction shock or because the worker finds a position in sector A:

$$
\begin{aligned}
& r J_{N}^{B}=h^{B}-w_{N}^{B}+s\left(V^{B}-J_{N}^{B}\right)+e o_{N} \cdot p\left(\theta^{A}\right)\left(V^{B}-J_{N}^{B}\right) \\
& r J_{I}^{B}=h^{B}-w_{I}^{B}+s\left(V^{B}-J_{I}^{B}\right)+e o_{I} \cdot p\left(\theta^{A}\right)\left(V^{B}-J_{I}^{B}\right)
\end{aligned}
$$

The average value of a filled vacancy in sector $\mathrm{B}$ results from the weighted average $\overline{J^{B}}=$ $\omega_{1}^{B} J_{I}^{B}+\left(1-\omega_{1}^{B}\right) J_{N}^{B}$, where $\omega_{1}^{B}=\frac{u_{I}^{B}}{\left(u_{N}^{B}+u_{I}^{B}+\lambda u_{N}^{A}+\lambda u_{I}^{A}\right)}$.

In sector A, the vacancy may be filled by a native worker (unemployed or coming from sector B) or by an immigrant (unemployed or coming from sector B). The decision concerning the number of vacancies to open is then also based on the average expected profit. We denote $V^{A}$ the value of an empty vacancy and $J_{N}^{A}, J_{N}^{A B}, J_{I}^{A B}$ and $J_{I}^{A}$ the values of a position filled, respectively, by a native worker previously unemployed, a native worker previously employed in sector B, an immigrant worker previously employed in sector B and an immigrant worker previously unemployed. These values are given by: 


$$
\begin{aligned}
r V^{A}= & -\gamma+q\left(\theta^{A}\right)\left(\overline{J^{A}}-V^{A}\right) \\
= & -\gamma+q\left(\theta^{A}\right)\left(\frac{u_{N}^{A}}{u_{N}^{A}+u_{I}^{A}+e o_{I} \cdot n^{B}+e o_{I} \cdot n_{I}^{B}} J_{N}^{A}+\frac{e o_{N} \cdot n_{N}^{B}}{u_{N}^{A}+u_{I}^{A}+e o_{N} \cdot n_{N}^{B}+e o_{I} \cdot n_{I}^{B}} J_{N}^{A B}\right. \\
+ & \left.\frac{e o_{I} \cdot n_{I}^{B}}{u_{N}^{A}+u_{I}^{A}+e o_{N} \cdot n_{N}^{B}+e o_{I} \cdot n_{I}^{B}} J_{I}^{A B}+\frac{u_{I}^{A}}{u_{N}^{z}+u_{I}^{z}+e o_{N} \cdot n_{N}^{B}+e o_{I} \cdot n_{I}^{B}} J_{I}^{A}-V^{B}\right) \\
& \text { where } \\
r J_{N}^{A}= & h^{A}-w_{N}^{A}+s\left(V^{A}-J_{N}^{A}\right) \\
r J_{N}^{A B}= & h^{A}-w_{N}^{A B}+s\left(V^{A}-J_{N}^{A B}\right) \\
r J_{I}^{A B}= & h^{A}-w_{I}^{A B}+s\left(V^{A}-J_{I}^{A B}\right) \\
r J_{I}^{A}= & h^{A}-w_{I}^{A}+s\left(V^{A}-J_{I}^{A}\right)
\end{aligned}
$$

where $h^{A}$ corresponds to the productivity of the job and $w_{N}^{A}, w_{N}^{A B}, w_{I}^{A B}$ and $w_{I}^{A}$ stand, respectively, for the wage of a native previously unemployed, for the wage of a native coming from sector B, for the wage of an immigrant coming from sector B and for the wage of an immigrant coming from unemployed. We denote as $\omega_{1}^{A}=\frac{u_{I}^{A}}{u_{N}^{A}+u_{I}^{A}+e o \cdot n_{N}^{B}+e o \cdot n_{I}^{B}}$ the proportion of immigrants job-seekers in sector A that were previously unemployed, $\omega_{2}^{A}=\frac{e o \cdot n_{I}^{B}}{u_{N}^{A}+u_{I}^{A}+e o \cdot n_{N}^{B}+e o \cdot n_{I}^{B}}$ the proportion of immigrants in sector A that were previously employed in sector B, the share of native job seekers coming from sector B equals $\omega_{3}^{A}=\frac{e o \cdot n_{N}^{B}}{u_{N}^{A}+u_{I}^{A}+e o \cdot n_{N}^{B}+e o \cdot n_{I}^{B}}$ and the proportion of native job seekers coming from unemployed is given by $\left(1-\omega_{1}^{A}-\omega_{2}^{A}-\omega_{3}^{A}\right)=\frac{u_{N}^{A}}{u_{N}^{A}+u_{I}^{A}+e o \cdot n_{N}^{B}+e o \cdot n_{I}^{B}}$.

Firms open vacancies until no more profit can be obtained so that, at the equilibrium, the free entry condition $V^{t}=0$ applies, i.e.:

$$
\frac{\gamma}{q\left(\theta^{A}\right)}=\overline{J^{A}} \quad \text { and } \quad \frac{\gamma}{q\left(\theta^{B}\right)}=\overline{J^{B}}
$$

where:

$$
\begin{aligned}
& \overline{J^{A}}=\frac{h^{A}-\omega_{1} w_{I}^{A}-\omega_{2} w_{N}^{A B}-\omega_{3} w_{I}^{A B}-\left(1-\omega_{1}-\omega_{2}-\omega_{3}\right) w_{N}^{A}}{r+s} \\
& \overline{J^{B}}=\omega_{1}^{B} J_{I}^{B}+\left(1-\omega_{1}^{B}\right) J_{N}^{B}=\omega_{1}^{B} \frac{h^{B}-w_{I}^{B}}{r+s+e o_{I} \cdot p\left(\theta^{A}\right)}+\left(1-\omega_{1}^{B}\right) \frac{h^{B}-w_{N}^{B}}{r+s+e o_{N} \cdot p\left(\theta^{A}\right)}
\end{aligned}
$$




\subsection{Wages}

We consider a wage determination process in the style of Hall and Milgrom (2008) so that the outcome of the symmetric alternating-offers game is :

$$
\begin{aligned}
w_{N}^{t} & =\eta h^{t}+(1-\eta) b_{N} \\
w_{I}^{t} & =\eta h^{t}+(1-\eta) b_{I}^{t} \\
w_{N}^{A B} & =\eta h^{A}+(1-\eta) w_{N}^{B} \\
w_{I}^{A B} & =\eta h^{A}+(1-\eta) w_{I}^{B}
\end{aligned}
$$

where $\eta$ can be interpreted as the bargaining power of each party and it is set to $1 / 2$.

\subsection{Employment opportunities}

Employment opportunities are measured by the labor market tightness which is determined by the free entry condition (41). Combining this equation with (42) and (43), yields:

$\frac{\gamma}{q\left(\theta^{A}\right)}=\bar{J}^{A}=\frac{h^{A}-\overline{w^{A}}}{r+s} \quad$ and $\quad \frac{\gamma}{q\left(\theta^{B}\right)}=\overline{J^{B}}=\omega_{1}^{B} \frac{h^{B}-w_{I}^{B}}{r+s+e o_{I} \cdot p\left(\theta^{A}\right)}+\left(1-\omega_{1}^{B}\right) \frac{h^{B}-w_{N}^{B}}{r+s+e o_{N} \cdot p\left(\theta^{A}\right)}$

Since $\frac{\gamma}{q\left(\theta^{t}\right)}=\frac{\gamma}{m_{0}}\left(\theta^{t}\right)^{1 / 2}$ for $t=A, B$, we find:

$\theta^{A}=\left(\frac{m_{0}\left(h^{A}-\overline{w^{A}}\right)}{\gamma(r+s)}\right)^{2} \quad$ and $\quad \theta^{B}=\left(\frac{m_{0}}{\gamma} \omega_{1}^{B} \frac{h^{B}-w_{I}^{B}}{r+s+e o_{I} \cdot p\left(\theta^{A}\right)}+\frac{m_{0}}{\gamma}\left(1-\omega_{1}^{B}\right) \frac{h^{B}-w_{N}^{B}}{r+s+e o_{N} \cdot p\left(\theta^{A}\right)}\right)^{2}$

where $\overline{w^{A}}=\omega_{1}^{A} w_{I}^{A}+\omega_{2}^{A} w_{I}^{A B}+\omega_{3}^{A} w_{N}^{A B}+\left(1-\omega_{1}^{A}-\omega_{2}^{A}-\omega_{3}^{A}\right) w_{N}^{A}$.

\subsection{The unemployment rates}

At the steady state, outflows from one sector must equal inflows. Moreover, inside every sector entries to unemployment must equal exits. Outflows from sector A (inflows towards sector B) equal $\lambda\left(u_{I}^{A}+u_{N}^{A}\right)$ while inflows to A (outflows from B) correspond to $\left(n_{I}^{B} e o_{I} p\left(\theta^{A}\right)+n_{N}^{B} e o_{N} p\left(\theta^{A}\right)\right)$. At the equilibrium:

$$
\lambda\left(u_{I}^{A}+u_{N}^{A}\right)=\left(n_{I}^{B} e o_{I} p\left(\theta^{A}\right)+n_{N}^{B} e o_{N} p\left(\theta^{A}\right)\right)
$$

Inside sector $\mathrm{A}$ outflows from unemployment equal $\lambda u^{A}+p\left(\theta^{A}\right) u^{A}$ where $u^{A}=\left(u_{I}^{A}+u_{N}^{A}\right)$. Inflows to unemployment equal $s n^{A}$, where $P^{A}=n^{A}+u^{A}$. Equalizing inflows and outflows 
from unemployment in sector A gives us the aggregate unemployment in sector A:

$$
u^{A}=\frac{s P^{A}}{\lambda+p\left(\theta^{A}\right)+s}
$$

Distinguishing between immigrants and natives we can compute in a similar manner the unemployment and employment rates:

$$
\begin{array}{rlrl}
u_{N}^{A} & =\frac{s P_{N}^{A}}{\lambda+p\left(\theta^{A}\right)+s} & u_{I}^{A}=\frac{s P_{I}^{A}}{\lambda+p\left(\theta^{A}\right)+s} \\
n_{N}^{A}=\frac{p\left(\theta^{A}\right) e o_{N} n_{N}^{B}+p\left(\theta^{A}\right) P_{N}^{A}}{s+p\left(\theta^{A}\right)} & n_{I}^{A}=\frac{p\left(\theta^{A}\right) e o_{I} n_{I}^{B}+p\left(\theta^{A}\right) P_{I}^{A}}{s+p\left(\theta^{A}\right)}
\end{array}
$$

Applying the same reasoning to sector B:

$$
\begin{aligned}
u^{B}=\frac{s P^{B}+\lambda u^{A}}{p\left(\theta^{B}\right)+s}, \quad u_{N}^{B}=\frac{s P_{N}^{B}+\lambda u_{N}^{A}}{p\left(\theta^{B}\right)+s} & \text { and } \quad u_{I}^{B}=\frac{s P_{I}^{B}+\lambda u_{I}^{A}}{p\left(\theta^{B}\right)+s} \\
n_{N}^{B}=\frac{p\left(\theta^{B}\right) P_{N}^{B}}{s+p\left(\theta^{A}\right) e o_{N}+p\left(\theta^{B}\right)} & n_{I}^{B}=\frac{p\left(\theta^{B}\right) P_{I}^{B}}{s+p\left(\theta^{A}\right) e o_{I}+p\left(\theta^{B}\right)}
\end{aligned}
$$


14_8. Health, Work and Working Conditions: A Review of the European Economic Literature

Thomas Barnay

14_7. Labour mobility and the informal sector in Algeria: a cross-sectional comparison (2007-2012)

Philippe Adair, Youghourta Bellache

14_6. Does care to dependent elderly people living at home increase their mental health? Thomas Barnay, Sandrine Juin

14_5. The Effect of Non-Work Related Health Events on Career Outcomes: An Evaluation in the French Labor Market

Emmanuel Duguet, Christine le Clainche

14_4. Retirement intentions in the presence of technological change: Theory and evidence from France

Pierre-Jean Messe, Eva Moreno - Galbis, Francois-Charles Wolff

14_3. Why is Old Workers' Labor Market more Volatile? Unemployment Fluctuations over the Life-Cycle

Jean-Olivier Hairault, François Langot, Thepthida Sopraseuth

14_2. Participation, Recruitment Selection, and the Minimum Wage

Frédéric Gavrel

14_1. Disparities in taking sick leave between sectors of activity in France: a longitudinal analysis of administrative data

Thomas Barnay, Sandrine Juin, Renaud Legal 
The CNRS Institute for Labor Studies and Public Policies (the TEPP Institute, FR $n^{\circ} 3435$ CNRS) gathers together research centres specializing in economics and sociology:

- l'Equipe de Recherche sur les Marchés, l'Emploi et la Simulation (Research Team on Markets, Employment and Simulation), ERMES, University of Paris II PanthéonAssas

- the Centre d'Etudes des Politiques Economiques de l'université d'Evry (Research Centre focused on the analysis of economic policy and its foundations and implications), EPEE, University of Evry Val d'Essonne

- the Centre Pierre Naville (Research on Work and Urban Policies), CPN, University of Evry Val d'Essonne

- l'Equipe de Recherche sur l'Utilisation des Données Temporelles en Economie (Research Team on Use of Time Data in Economics), ERUDITE, University of ParisEst Créteil and University of Paris-Est Marne-la-Vallée

- the Groupe d'Analyse des Itinéraires et des Niveaux Salariaux (The Group on Analysis of Wage Levels and Trajectories), GAINS, University of the Maine

The TEPP Institute brings together 147 researchers and research professors and $100 \mathrm{PhD}$ students who study changes in work and employment in relation to the choices made by firms and analyse public policies using new evaluation methods. 